\title{
Marriage stability, taxation and aggregate labor supply in the U.S. vs. Europe
}

\author{
Indraneel Chakraborty ${ }^{\mathrm{a}, \mathrm{b}, *}$, Hans A. Holter ${ }^{\mathrm{c}}$, Serhiy Stepanchuk ${ }^{\mathrm{d}}$ \\ a Southern Methodist University, United States \\ ${ }^{\mathrm{b}}$ University of Miami, United States \\ ${ }^{\mathrm{c}}$ University of Oslo, Norway \\ d École Polytechnique Fédérale de Lausanne, Switzerland
}

\section{A R T I C L E I N F O}

\section{Article history:}

Received 11 November 2012

Received in revised form

6 January 2015

Accepted 7 January 2015

Available online 21 January 2015

\section{Keywords:}

Aggregate labor supply

Taxation

Marriage

Divorce

Heterogeneous households

\begin{abstract}
A B S T R A C T
Americans work more than Europeans. Using micro-data from the United States and 17 European countries, we document that women are typically the largest contributors to the cross-country differences in work hours. We also show that there is a negative relation between taxes and annual hours worked, driven by men, and a positive relation between divorce rates and annual hours worked, driven by women. In a calibrated life-cycle model with heterogeneous agents, marriage and divorce, we find that the divorce and tax mechanisms together can explain $45 \%$ of the variation in labor supply between the United States and the European countries.
\end{abstract}

(c) 2015 Elsevier B.V. All rights reserved.

\section{Introduction}

It is a well-known empirical finding that aggregate hours worked are higher in the United States than in Europe and that there is also substantial variation among European countries; see for instance Prescott (2004) and Rogerson (2006). These differences deserve attention: Rogerson (2006) notes that they are an order of magnitude larger than the fluctuations at business cycle frequencies in post-WWII U.S. data. Are the differences in hours worked due to public policies or are they due to other fundamental differences between societies?

This paper has two contributions: first, it documents, using cross-country data, that there is a negative relation between taxes and annual hours worked and a positive relation between divorce rate and annual hours worked. While the first relation is well-known, the second one is new, at least from a cross-country perspective. Furthermore, this paper shows that the negative relation between taxes and hours is driven by the behavior of men (i.e. for women the correlation between taxes and hours is close to zero) and the positive relation between divorce and hours is driven by the behavior of women (i.e. for men the correlation between divorce and hours is close to zero).

Second, motivated by these two facts, this paper builds a life cycle model economy populated by heterogenous agents in which both taxes and marital instability affect hours of work. In the model economy, the marital transitions are exogenous, but given these exogenous transitions agents adjust their labor supply and savings behavior. An important assumption is that the labor force participation is associated with higher future earnings, as agents accumulate experience. The model is

\footnotetext{
* Correspondence to: 6212 Bishop Blvd., Dallas, TX 75275-0333, United States. Tel.: +1312 2081283.

E-mail addresses: indranil@alum.mit.edu (I. Chakraborty), hans.holter@econ.uio.no (H.A. Holter), serhiy.stepanchuk@epfl.ch (S. Stepanchuk).
} 
then calibrated to the U.S. and is used to evaluate how much cross-country differences in taxes and marriage and divorce rates can account for cross-country differences in hours worked. To this end, we use the calibrated economy and change taxes and/or marriage and divorce rates. The results show that taxes play an important role for differences in male hours, while differences in marriage and divorce explain differences in female hours.

We begin by using micro-level data to document the contribution of various demographic groups to the aggregate differences in hours worked between the U.S. and 17 European countries (Western Europe, except Iceland and Lichtenstein). We divide the populations into 12 demographic groups, by age, gender and marital status, and find that the largest contribution comes from prime-aged women. In most European countries, women work substantially less than in the United States while the difference in hours worked between European and American men is smaller. ${ }^{1}$ This is especially true for married women, but also holds for single women, and for women with and without children. Next, we document the main motivation for this paper: a negative cross-country correlation between tax levels and hours worked, and a positive correlation between divorce rates and hours worked across countries. However, taxes are in particular correlated with male work hours, while divorce rates are in particular correlated with female work hours.

Why should divorce rates affect labor supply? The value of marriage as consumption insurance has been pointed out in the literature. ${ }^{2}$ This paper argues that a higher probability of divorce affects labor supply by reducing the expected value of insurance provided by marriage. In response, individuals self-insure by investing in experience accumulation in the labor market. The argument also applies to individuals who have not yet married. Thus, differences in divorce rates can help explain cross-country differences in labor supply.

To quantitatively assess the impact of taxes and marriage stability on labor supply, we develop a life-cycle, overlappinggenerations model with heterogeneous agents, marriage and divorce. There are three types of households: single men, single women and married couples. Divorces and marriages occur stochastically. ${ }^{3}$ We calibrate our model to U.S. data and study how labor supply in the U.S. changes as we introduce divorce and marriage probabilities and tax systems from other countries. We find that making marriages more stable results in a reduction of labor supply, particularly for women. This is because women are usually the second earners in a married couple. The insurance effect of marriage is therefore stronger for women, and female labor supply is more sensitive to divorce and marriage rates.

When treated with both divorce and marriage probabilities and tax systems from the European countries at the same time, the model can explain $45 \%$ of the variation in aggregate labor supply between the U.S. and the European countries. Changing only the probabilities of marriage and divorce in the U.S. to their European equivalents accounts for $17 \%$ of the cross-country differences in aggregate hours worked. When we only introduce European taxes, we can account for $32 \%$ of the variation in aggregate hours worked between the U.S. and the European countries. For female labor supply, marriage stability explains $22 \%$ of the variation in work hours. However, taxes are unable to explain any variation in female labor supply. Taxes are on the other hand very good predictors of male labor supply. For men, taxes explain $71 \%$ of the variation between the U.S. and the 17 European countries compared to 9\% explained by divorce and marriage rates. In Section 6 we relate the differential impact of taxation on male and female labor supply to the fact that countries with high tax average levels also tend to have progressive taxes and separate taxation of married couples.

There is a substantial literature devoted to the rise in female work hours in the US over time. The same explanations may be important from a cross country perspective. Divorce rates have been shown to have a significant effect on female labor supply (see Johnson and Skinner, 1986; Stevenson, 2008). In a contemporary paper which is closely related to ours, Fernández and Wong (2013) find that divorce rates can help explain the rise in female labor force participation over time in the U.S. Building a life-cycle model and treating it with exogenous divorce and marriage rates the authors can explain a significant fraction of the increase in labor force participation of married women in the 1955 cohort compared to the 1935 cohort. The rest is explained by changes in wage structure. Kaygusuz (2010) finds that $20-24 \%$ of the $13 \%$ points rise in labor force participation of U.S. married women between 1980 and 1990 can be explained by changes in taxes. In another related contemporary paper by Guvenen and Rendall (2013), women can achieve insurance against a bad marriage through education. Guvenen and Rendall (2013) are able to explain the rise in divorce and decline in marriage rates in U.S. using their framework. Attanasio et al. (2008) look at the lifecycle labor supply of American women born in the 1930s, 1940s and 1950s and find that a combination of a reduction in the cost of children alongside a reduction in the wage-gender gap is needed to explain the increase in participation of the youngest cohort. Jones et al. (2003) study the increase in labor supply of married women in U.S. between 1950 and 1990 and find that the gender wage gap plays an important role, while technological improvements in the household have limited impact on the increase in labor supply by married women. On the other hand, Greenwood et al. (2005) find that new household technologies can help explain the rise in married female labor force participation. Fernández et al. (2004) argue that changes in characteristics of men - whose mothers have worked themselves - help explain the labor participation decisions of their wives.

\footnotetext{
${ }^{1}$ The Nordic countries are an exception.

${ }^{2}$ See for instance Kotlikoff and Spivak (1981) who study the gains from marriage due to risk sharing. Johnson and Skinner (1986) and Stevenson (2008) have shown that divorce rates have significant effects on female labor supply.

${ }^{3}$ Two recent papers also making the assumption of exogenous divorce and marriage rates are Cubeddu and Rios-Rull (2003) and Fernández and Wong (2013). This is reasonable because literature has shown that cultural, legal and birth control factors play an important role for cross-country differences in divorce and marriage rates (See Johnson and Skinner, 1986; Goldin and Katz, 2002; Crouch and Beaulieu, 2006; Stevenson, 2008; McDermott et al., 2009; Gonzalez and Viitanen, 2009; Furtado et al., 2010; Kennes and Knowles, 2012 among others).
} 
A contemporary paper which is related to ours, and which also investigates the relationship between taxes and labor supply across countries, is Bick and Fuchs-Schundeln (2014). Using a static model with two-person households, they concentrate on the labor supply of married couples. The authors find that introducing European tax systems into their model, which is calibrated to the U.S., does well in explaining cross country differences in male work hours. For countries which, similar to the U.S., practice joint taxation of married couples, ${ }^{4}$ taxes also help explaining differences in female work hours. For countries who practice a higher degree of separate taxation of married couples, taxes explain less of the differences in female labor supply. The reason is that some of the countries with relatively high average tax rate practice separate taxation and in addition have very progressive tax schedules. The tax rate on the secondary earner (usually the female) is therefore not necessarily that different from the U.S. This is similar to what we find in Section 6.3.

Other mechanisms that may affect differences in work hours across countries have also been investigated in the literature. In particular, Rendall (2011) investigates differential productivity across sectors, Alesina et al. (2005) suggest regulations and unionization, Wallenius (2012) considers social security systems and resulting redistributive effects and Olivetti (2006) looks at the role of returns to experience. We partially capture the redistributive effects in our model, but due to data limitations are unable to capture country specific gender wage gaps, returns to labor market experience, and unionization effects. These mechanisms could also contribute to explaining cross-country differences in work hours. While we do not expect that our two mechanisms can explain all of the cross-country variation in hours, in Section 6 we find that they explain a substantial fraction (45\%).

The remainder of the paper is organized as follows: in Section 2, we study the contributions of different demographic groups to aggregate differences in labor supply between the U.S. and 17 Western European countries. In Section 3, we document a correlation between aggregate labor supply and taxation across countries and a correlation between aggregate labor supply and divorce rates across geographic regions. Section 4 develops the quantitative model. Section 5 discusses data and calibration. Section 6 studies the quantitative implications of changing the U.S. divorce and marriage probabilities to their European counterparts, and quantitative implications of introducing European tax schemes in the U.S. Section 7 concludes.

\section{Labor supply in the U.S. and Europe}

This section analyzes the data for the annual hours worked in the U.S. and Europe.

\subsection{Data description}

To obtain information about annual hours worked, we use two sources of micro-data - the European Union Labor Force Survey database (E.U. LFS), which contains data from the 17 European countries in our sample, and the Current Population Survey (CPS), which contains the corresponding data from the U.S. Both of these datasets are used by the OECD to construct their macro-level labor market statistics. We use data from 2000 for all countries except Germany, for which E.U. LFS data is only available from 2002.

Similar to Prescott (2004), we consider individuals between 15 and 64 years of age. We construct the data on annual hours worked as the product of hours worked per week and the number of weeks worked per year. We provide further details and discuss some existing issues with the data in Appendix A. ${ }^{5}$

\subsection{Labor supply across countries}

Column (2) in Table 1 shows that when taking a simple average across all European countries in our sample, in the year 2000 European hours worked were $81.70 \%$ of (or about 249 hours less than) those in the U.S. At the same time, there is a substantial variation within Europe. The annual hours worked in Switzerland were quite close to those in the U.S., while in Belgium they were only $69.18 \%$ of (or more than $400 \mathrm{~h}$ lower than) those in the U.S.

Columns (3) and (4) in Table 1 show cross-country differences in hours worked for men and women separately. On average, the difference for women is about $45 \%$ larger than for men. However, the average masks a large variation within Europe. We divide the European countries in our sample in three subgroups: Nordic countries, Central Europe and Southern Europe. ${ }^{6}$ In the Nordic countries, the difference from the U.S. is in fact larger for men, while in a typical Southern European country (with the only exception of Portugal), the difference for women is about two to three times larger than the corresponding difference for men.

Columns (5)-(8) in Table 1 compare the average annual hours worked by marital status. Among the four gender/marital status groups shown in the table (married men, single men, married women and single women), married women in Europe display the largest difference from their U.S. counterparts. However, this is largely due to the behavior of married women in Central and Southern European countries. In Nordic countries, married women work almost as many hours as those in the

\footnotetext{
${ }^{4}$ Germany and Belgium would be examples of such countries.

${ }^{5}$ Internet supplement is available at http://ees.elsevier.com/monec/download.aspx?id=80486\&guid=f0c00206-bc0b-408b-a050-eac8f9f521bc\& scheme $=1$.

${ }^{6}$ We put Ireland in the "Southern" European group, since it resembles those countries along two important dimensions: marriage stability and labor supply of women. It might be more appropriate to call this group of countries "Catholic".
} 
Table 1

Annual hours worked, all persons 15-64 years of age. Hours worked per year for the U.S., percent of the U.S. for other countries.

\begin{tabular}{|c|c|c|c|c|c|c|c|c|c|c|c|c|c|}
\hline Country: & (2) & Men & Women & $\begin{array}{l}\text { Men, } \\
\text { married } \\
(5)\end{array}$ & $\begin{array}{l}\text { Women, } \\
\text { married } \\
(6)\end{array}$ & $\begin{array}{l}\text { Men, } \\
\text { single } \\
\text { (7) }\end{array}$ & $\begin{array}{l}\text { Women, } \\
\text { single } \\
\text { (8) }\end{array}$ & $\begin{array}{l}\text { Men, } \\
15- \\
24 \mathrm{yr} \\
(9)\end{array}$ & $\begin{array}{l}\text { Women, } \\
15-24 \mathrm{yr} \\
(10)\end{array}$ & $\begin{array}{l}\text { Men, } \\
25- \\
54 \mathrm{yr} \\
(11)\end{array}$ & $\begin{array}{l}\text { Women, } \\
25-54 \mathrm{yr} \\
(12)\end{array}$ & $\begin{array}{l}\text { Men, } \\
55- \\
64 \mathrm{yr} \\
(13)\end{array}$ & $\begin{array}{l}\text { Women, } \\
55-64 \mathrm{yr} \\
(14)\end{array}$ \\
\hline \multicolumn{14}{|c|}{ Nordic countries: } \\
\hline Denmark & 88.80 & 87.95 & 91.98 & 81.10 & 92.90 & 107.00 & 88.30 & 136.10 & 121.80 & 82.40 & 88.60 & 77.80 & 72.20 \\
\hline Finland & 86.92 & 83.33 & 91.45 & 80.90 & 98.50 & 97.40 & 83.40 & 108.40 & 98.20 & 85.10 & 95.50 & 56.40 & 70.10 \\
\hline Norway & 83.32 & 84.86 & 79.96 & 81.90 & 81.90 & 98.80 & 76.50 & 108.70 & 93.50 & 79.70 & 77.00 & 90.70 & 82.90 \\
\hline Sweden & 89.72 & 86.18 & 93.99 & 83.40 & 99.50 & 104.20 & 88.40 & 89.30 & 87.80 & 84.40 & 92.80 & 87.20 & 100.70 \\
\hline Group mean: & 87.19 & 85.58 & 89.34 & 81.83 & 93.20 & 101.85 & 84.15 & 110.62 & 100.33 & 82.90 & 88.48 & 78.02 & 81.48 \\
\hline \multicolumn{14}{|c|}{ Central Europe: } \\
\hline Austria & 83.24 & 88.76 & 75.38 & 80.00 & 66.40 & 107.30 & 86.50 & 136.30 & 129.60 & 90.20 & 78.00 & 56.00 & 30.80 \\
\hline Belgium & 69.18 & 74.89 & 60.96 & 71.80 & 59.00 & 81.10 & 61.80 & 69.80 & 62.20 & 80.20 & 68.30 & 42.80 & 20.70 \\
\hline France & 72.18 & 74.98 & 68.22 & 74.10 & 69.40 & 81.60 & 65.50 & 68.10 & 57.60 & 81.10 & 74.50 & 42.70 & 39.40 \\
\hline Germany & 71.00 & 74.68 & 64.93 & 69.50 & 55.70 & 86.40 & 76.90 & 96.90 & 104.40 & 75.10 & 66.30 & 57.60 & 38.80 \\
\hline Luxembourg & 76.60 & 85.96 & 62.07 & 82.50 & 55.60 & 86.40 & 72.50 & 76.40 & 66.00 & 92.30 & 66.20 & 50.60 & 27.30 \\
\hline Netherlands & 76.01 & 88.19 & 57.81 & 81.80 & 47.80 & 99.60 & 72.90 & 105.90 & 102.50 & 87.40 & 55.70 & 63.60 & 27.10 \\
\hline Switzerland & 97.24 & 107.68 & 84.89 & 98.00 & 60.10 & 130.50 & 113.20 & 141.40 & 161.40 & 98.70 & 79.30 & 109.20 & 66.90 \\
\hline UK & 90.17 & 97.47 & 80.85 & 92.60 & 76.30 & 110.10 & 84.80 & 126.10 & 122.30 & 95.50 & 79.70 & 85.50 & 55.60 \\
\hline Group mean: & 79.45 & 86.58 & 69.39 & 81.29 & 61.29 & 97.88 & 79.26 & 102.61 & 100.75 & 87.56 & 71.00 & 63.50 & 38.33 \\
\hline \multicolumn{14}{|l|}{ South Europe: } \\
\hline Greece & 87.09 & 98.35 & 71.73 & 95.70 & 72.10 & 100.60 & 67.20 & 99.10 & 76.20 & 100.80 & 76.60 & 92.40 & 55.00 \\
\hline Ireland & 82.17 & 92.35 & 66.55 & 92.10 & 55.80 & 101.80 & 77.70 & 121.70 & 105.70 & 92.40 & 66.40 & 94.40 & 39.90 \\
\hline Italy & 73.70 & 84.54 & 58.37 & 82.50 & 54.70 & 87.60 & 62.20 & 78.70 & 63.10 & 89.30 & 63.50 & 60.10 & 29.70 \\
\hline Portugal & 88.57 & 90.62 & 85.60 & 87.70 & 89.10 & 91.80 & 74.70 & 123.50 & 98.60 & 90.80 & 91.20 & 88.50 & 69.30 \\
\hline Spain & 73.04 & 83.45 & 58.00 & 83.60 & 52.60 & 85.30 & 64.10 & 95.30 & 72.40 & 85.30 & 61.40 & 78.50 & 36.50 \\
\hline Group mean: & 80.91 & 89.86 & 68.05 & 88.32 & 64.86 & 93.42 & 69.18 & 103.66 & 83.20 & 91.72 & 71.82 & 82.78 & 46.08 \\
\hline $\begin{array}{l}\text { Overall } \\
\text { mean: }\end{array}$ & 81.70 & 87.31 & 73.69 & 83.48 & 69.85 & 97.50 & 77.45 & 104.81 & 95.49 & 87.69 & 75.35 & 72.59 & 50.76 \\
\hline $\begin{array}{l}\text { United } \\
\text { States }\end{array}$ & 1360.40 & 1613.00 & 1121.30 & 1931.70 & 1171.90 & 1191.30 & 1087.50 & 714.30 & 574.30 & 1951.90 & 1332.00 & 1354.80 & 894.80 \\
\hline
\end{tabular}

Note: This table reports the annual hours worked by each group as a fraction of the respective U.S. group in the year 2000. Column (2) shows the average annual hours worked per European country in our sample. Columns (3) and (4) show cross-country differences in hours worked for men and women separately. We divide the European countries in our sample in 3 subgroups: Nordic countries, Central Europe and Southern Europe. Columns (5)-(8) compare the average annual hours worked by marital status. Columns (9)-(14) compare the cross-country differences in hours worked by gender and 3 age groups: (i) “young" (16-24 years of age), (ii) "prime-aged" (25-54 years of age) and (iii) "old” (55-64 years of age). Column (2) shows that the average work hours in Europe are $81.70 \%$ of (or about 249 hours less than) those in the U.S. Columns (3) and (4) show that the difference in work hours for women is about $45 \%$ larger than for men. There is large variation within Europe. The difference in work hours is driven by Southern European women, where the difference for women is about two to three times larger than the corresponding difference for men. Columns (5)-(8) show that married women in Central and Southern Europe display the largest difference from their U.S. counterparts. Columns (9)-(14) show that among the three age groups, the largest difference is displayed by the "old" European men and women. However, due to the relative sizes of the age groups, prime-aged persons (and in particular prime-aged women) are typically the largest contributors to the aggregate difference with the U.S.

U.S. Single women in Europe also work substantially less compared to their U.S. counterparts, and the difference is again particularly large in Southern Europe.

We use legal marital status in our analysis. Cohabitation is an important issue. However, data is mostly unavailable regarding cohabiting couples. Eurostat database that we use to compute the marriage and divorce probabilities provides data on persons in registered partnership for only four countries in our sample: the Netherlands, Denmark, Finland and Sweden, starting from 2007. In Appendix B, we discuss the impact of cohabitation on these four countries in some detail. The impact of cohabitation for the four countries seems limited. However, more research using more data is necessary before a conclusion can be reached. At the same time, we believe that people that are legally married and those that only cohabit differ along the dimensions (such as separation costs and tax schedule) that are mainly relevant for this paper. The existing research on this matter appears to support this view (see, for example, Gemici and Laufer, 2010). ${ }^{7}$

Columns (9)-(14) in Table 1 contrasts the cross-country differences in hours worked by gender and three age groups: (i) "young" (16-24 years of age), (ii) "prime-aged" (25-54 years of age) and (iii) "old" (55-64 years of age). As before, for each age group, the difference is larger for women. Among the three age groups, the largest difference from the corresponding reference group in the U.S. on average is displayed by the "old" European men and women. However, as we will discuss later, because of the relative sizes of the age groups, prime-aged persons (and in particular prime-aged women) are typically the largest contributors to the aggregate difference with the U.S.

\footnotetext{
${ }^{7}$ In a few European countries, cohabitation is quite similar to marriage (see Perelli-Harris and Gassen, 2012).
} 
Given that we find that the difference in hours worked between the U.S. and Europe is larger for women than for men, it is natural to ask whether this is related to women reducing their labor supply as a result of having children.

Panel A of Table H.14 in the Appendix shows that when we concentrate on a narrower age group (20-30 years of age), we find that these younger women without small children in Europe typically have annual hours of work that are closer to their American counterparts. This is in comparison to the same group of young women with small children, where we find a larger gap in work hours. This pattern is especially true for countries like Austria and Germany. Comparing Columns (2) and (4) for those two nations shows that numbers drop from $100.3 \%$ and $82.9 \%$ of U.S. hours to $57.1 \%$ and $37.2 \%$ of the U.S. hours for Austria and Germany respectively. ${ }^{8}$

Next, we investigate the contribution of women with small children to the overall difference in annual hours worked, with respect to U.S. Panel B of Table H.14 in the Appendix shows that the contribution of women with small children to the overall difference in annual hours worked, with respect to the U.S., is typically substantially smaller than the contribution of women without small children. This is intuitive because the annual hours worked by women with small children is generally lower than other groups in both U.S. and Europe, and this group is not very large. Hence, the explanatory power of the difference in annual hours worked by women with small children is itself low. This is the reason why while children may play an important role in labor supply of young women, the presence of children does not play such a significant role in the difference of labor supply between U.S. and Europe. Bick and Fuchs-Schundeln (2014) also do not find that women with small children are a major contributor to the difference in labor supply between U.S. and European countries. However, more research needs to be done on this important sub-group of population.

\subsection{Group contribution decomposition}

To analyze the contributions of various demographic groups to the difference between aggregate labor supply in the U.S. and the European countries in our sample, we perform the following decomposition. Suppose we divide each country's sample into $n$ different groups. Then the difference between the aggregate average annual hours worked in the U.S., $\bar{h}^{u s}$, and in country $j, \bar{h}^{j}$, can be written as

$$
\bar{h}^{u s}-\bar{h}^{j}=\sum_{i=1}^{n} \omega_{i}^{u s} h_{i}^{u s}-\sum_{i=1}^{n} \omega_{i}^{j} h_{i}^{j}=\underbrace{\sum_{i=1}^{n}\left(h_{i}^{u s}-h_{i}^{j}\right) \omega_{i}^{u s}}_{\text {"behavioral effect" }}+\underbrace{\sum_{i=1}^{n}\left(\omega_{i}^{u s}-\omega_{i}^{j}\right) h_{i}^{j}}_{\text {"compositional effect" }}
$$

where $\omega_{i}^{j}$ is the share of observations that come from group $i$ in country $j$ 's sample, while $h_{i}^{j}$ is the average annual hours worked by individuals in this group. ${ }^{9}$ The last term in Eq. (1), which we call the "compositional" effect, reflects the differences in hours worked due to the differences in the composition of the population in the two countries. For instance, a positive compositional effect would mean that in the U.S., the demographic groups that typically work more (such as primeaged men) have relatively larger size, and the demographic groups that typically work less (such as older women) have smaller size compared to the corresponding European country $j$. We are more interested in the first term which we call the "behavioral effect". It captures the differences in hours worked by various demographic groups in the two countries, assuming that the composition of the population in these two countries is the same.

We divide the data into 12 demographic groups, according to gender, marital status and age (using three age groups). Table 2 reports the contribution of various demographic groups to the difference in aggregate labor supply. Columns (2) and (3) divide the population by gender, and add up to one. Columns (4)-(6) divide the population by age, i.e. Young, Prime-aged and Old, and add up to one as well. As can be seen from Column (7) in Table 2, the compositional effect is typically small. On average, it accounts for $6.6 \%$ of the difference between the U.S. and the European countries in our dataset. The rest of the difference is due to the behavioral effect. Columns (8) and (9) report the intensive and extensive margins, and add up to one.

Columns (2)-(6) in Table 2 show the contribution of several demographic groups of interest to the behavioral effect (while Table H.11 in the Appendix provides more details). To compute the weighted means for the three subgroups, and for all European countries in our sample, we weight them according to the size of the difference from the U.S. ${ }^{10}$ The table shows that in Central and especially in Southern Europe, women are the main contributors to the differences in hours worked between the U.S. and the European countries. In particular, the biggest contribution in these two groups of countries is coming from married prime-aged women. In contrast to this, in the Nordic countries, the biggest contribution comes from married prime-aged men.

As we mentioned earlier, the largest difference in terms of hours worked per person is displayed by older persons. However, because of the small size of that demographic group, their contribution to the overall difference is much smaller than the contribution of the prime-aged individuals.

\footnotetext{
${ }^{8}$ Table H.14 contains only a subset of countries for which E.U. LFS provide information on children.

${ }^{9}$ This is similar to the decomposition performed in Blundell et al. (2011). They analyze the changes in hours worked over time, while we look at the differences in hours worked between countries at a given point in time.

${ }^{10}$ We use the weights $\omega_{i}=\Delta_{U . S ., i} / \sum_{i} \Delta_{U . S ., i}$. One feature of such a weighting scheme is that it puts lower weight on Switzerland, which appears to be a special case. The difference between the U.S. and Switzerland is very small to begin with and therefore a relatively small absolute difference for one demographic group can be a large percentage difference.
} 
Table 2

Contribution of demographic groups to overall difference in annual hours worked, with respect to the U.S.

\begin{tabular}{|c|c|c|c|c|c|c|c|c|}
\hline $\begin{array}{l}\text { Country } \\
\text { (1) }\end{array}$ & $\begin{array}{l}\text { Men } \\
(2)\end{array}$ & $\begin{array}{l}\text { Women } \\
\text { (3) }\end{array}$ & $\begin{array}{l}\text { Young } \\
(4)\end{array}$ & $\begin{array}{l}\text { Prime-aged } \\
\text { (5) }\end{array}$ & $\begin{array}{l}\text { Old } \\
(6)\end{array}$ & $\begin{array}{l}\text { Composition } \\
\text { (7) }\end{array}$ & $\begin{array}{l}\text { Intensive margin } \\
(8)\end{array}$ & $\begin{array}{l}\text { Extensive margin } \\
\text { (9) }\end{array}$ \\
\hline \multicolumn{9}{|l|}{ Nordic countries } \\
\hline Denmark & 62.3 & 37.7 & -31.4 & 105.9 & 25.5 & 8.9 & 124.0 & -24.0 \\
\hline Finland & 73.6 & 26.4 & -6.7 & 69.5 & 37.2 & 18.8 & 35.4 & 64.6 \\
\hline Norway & 49.1 & 50.9 & -2.1 & 94.8 & 7.3 & -3.9 & 124.4 & -24.4 \\
\hline Sweden & 73.0 & 27.0 & 7.9 & 85.2 & 6.9 & 6.9 & 102.7 & -2.7 \\
\hline \multicolumn{9}{|l|}{ Central Europe } \\
\hline Austria & 36.6 & 63.4 & -24.7 & 82.6 & 42.1 & 17.0 & 57.8 & 42.2 \\
\hline Belgium & 47.7 & 52.3 & 9.4 & 66.5 & 24.1 & 4.4 & 51.4 & 48.6 \\
\hline Netherlands & 30.9 & 69.1 & -3.0 & 80.6 & 22.4 & -4.0 & 91.0 & 9.0 \\
\hline Germany & 50.3 & 49.7 & -0.7 & 81.1 & 19.6 & 5.4 & 68.2 & 31.8 \\
\hline Switzerland & -74.8 & 174.8 & -138.6 & 211.4 & 27.3 & -40.2 & 34.4 & 65.6 \\
\hline France & 50.8 & 49.2 & 11.5 & 64.7 & 23.8 & 5.3 & 48.0 & 52.0 \\
\hline Luxembourg & 36.4 & 63.6 & 10.0 & 61.3 & 28.7 & 8.0 & 40.5 & 59.5 \\
\hline UK & 12.1 & 87.9 & -30.6 & 98.0 & 32.5 & 9.1 & 75.3 & 24.7 \\
\hline \multicolumn{9}{|l|}{ Southern Europe } \\
\hline Greece & 0.4 & 99.6 & 5.0 & 67.6 & 27.4 & 22.5 & -120.2 & 220.2 \\
\hline Ireland & 15.0 & 85.0 & -10.8 & 91.9 & 19.0 & 11.8 & 35.7 & 64.3 \\
\hline Italy & 33.9 & 66.1 & 9.9 & 67.2 & 22.9 & 6.0 & -5.2 & 105.2 \\
\hline Portugal & 52.7 & 47.3 & -17.7 & 90.5 & 27.2 & 26.3 & 33.8 & 66.2 \\
\hline Spain & 33.6 & 66.4 & 3.8 & 79.0 & 17.2 & 9.8 & 21.2 & 78.8 \\
\hline$R^{2}$ & - & - & - & - & - & - & 0.138 & 0.423 \\
\hline Mean: & 34.3 & 65.7 & -12.3 & 88.1 & 24.2 & 6.6 & 63.3 & 36.7 \\
\hline Mean (weighted): & 39.7 & 60.3 & -2.3 & 78.8 & 23.5 & 7.6 & 49.6 & 50.4 \\
\hline Mean (Nordic): & 63.0 & 37.0 & -7.7 & 88.9 & 18.8 & 6.9 & 97.3 & 2.7 \\
\hline Mean (Central): & 39.3 & 60.7 & -2.1 & 76.0 & 26.1 & 4.8 & 64.1 & 35.9 \\
\hline Mean (South): & 28.0 & 72.0 & 0.3 & 78.0 & 21.7 & 12.8 & -5.7 & 105.7 \\
\hline
\end{tabular}

Note: This table reports the contributions of various demographic groups to the difference between aggregate labor supply in the U.S. and the European countries in our sample. Each column captures the differences in hours worked by various demographic groups in the two countries, assuming that the composition of the population in these two countries is the same. The data is divided into 12 demographic groups, according to gender, marital status and age (using three age groups). Columns (2) and (3) divide the population by gender, and add up to one. Columns (4)-(6) divide the population by age, i.e. Young, Prime-aged and Old, and add up to one as well. Column (7) reports the compositional effect, i.e. the differences in hours worked due to the differences in the composition of the population in the two countries. This is typically small, and on average, accounts for $6.6 \%$ of the difference between the U.S. and the European countries in our dataset. Columns (8) and (9) report the intensive and extensive margins, and add up to one. The table shows that in Central and Southern Europe, women - specifically married prime-aged women - are the main contributors to the differences in hours worked between the U.S. and the European countries. Older persons' contribution to the overall difference is much smaller than the contribution of the prime-aged individuals due to the smaller size of group.

\subsection{Intensive vs. extensive margin}

In this subsection we investigate whether the discrepancies in work hours between the U.S. and Europe are due to Americans working longer hours (intensive margin) or whether they are due to more Americans working (extensive margin). We find that the two margins are about equally important.

The two last columns of Table 2 show the contribution of the intensive and extensive margins to the difference in labor supply between the U.S. and country $i$, using the following decomposition formula:

$$
\begin{aligned}
\bar{h}^{\text {U.S. }} & -\bar{h}^{i}=H_{\mathrm{empl}}^{\text {U.S. }} \cdot \text { Share }_{\mathrm{empl}}^{\text {U.S. }}-H_{\mathrm{empl}}^{i} \cdot \text { Share }_{\mathrm{empl}}^{i} \\
= & \underbrace{\left(H_{\mathrm{empl}}^{\text {U.S. }}-H_{\mathrm{empl}}^{i}\right) \text { Share }_{\mathrm{empl}}^{U . S .}}_{\text {Intensive Margin }}+\underbrace{\left(\text { Share }_{\mathrm{empl}}^{\text {U.S. }}-\text { Share }_{\mathrm{empl}}^{i}\right) H_{\mathrm{empl}}^{i}}_{\text {Extensive Margin }}
\end{aligned}
$$

From the OECD data, one can compute the total average hours worked in country $i, H^{i}$, as the product of the hours worked by employed persons, $H_{\mathrm{empl}}^{i}$, and the share of the population which is employed, Share ${ }_{\mathrm{empl}}^{i}$. Table 2 reports the contributions of intensive and extensive margins as a percentage of the total difference in hours worked between the U.S. and country $i$, $\bar{h}^{U . S .}-\bar{h}^{i}$. As can be seen from the table, both margins appear to be important. The contribution of the extensive margin is particularly large in Southern Europe, while the intensive margin is more important in the Nordic countries, Netherlands and Germany (with Switzerland being a special case).

\section{Possible determinants of labor supply: taxes and marriage stability}

Taxes have been suggested as a major contributor to cross country differences in labor supply in the literature (see Prescott, 2004; Rogerson, 2006). Marriage stability is a new explanation in this context, motivated by our finding in Section 2 
that women are the biggest contributor to the cross-country differences in labor supply. Our hypothesis is that more stable marriages provide consumption insurance, thereby reducing the incentives to accumulate labor market experience, in particular for women who often are secondary earners. Conversely, a higher probability of divorce can increase the value of market experience for the woman who has a higher probability of ending up as a single earner.

It is well-known that the level of labor income taxes is higher in Europe (see Prescott, 2004). However, there are many issues to consider when comparing labor income taxes across countries. Both the cross-country differences in tax levels and tax progressivity may be of interest. We use three measures that capture some elements of the cross-country differences in tax progressivity: (1) top marginal tax rates, (2) progressivity wedge (PW) measure from Guvenen et al. (2014): ${ }^{11}$

$$
P W\left(y_{1}, y_{2}\right)=1-\frac{1-\tau\left(y_{2}\right)}{1-\tau\left(y_{1}\right)}
$$

This intuitive measure, where a higher value indicates a more progressive tax schedule, takes values between 0 and 1 but will naturally be sensitive to the choice of $y_{1}$ and $y_{2}$, except with flat taxes. If there is a flat tax, then the progressivity wedge would be zero for all levels of $y_{1}$ and $y_{2}$. Table H.10 in the Appendix shows that according to this measure, among the 18 countries in the table, Denmark has the most progressive taxes and Switzerland the least progressive. The U.S. is among the countries with the least progressive taxes, while Germany is among the countries with the most progressive taxes.

Consumption taxes may also have an impact on labor supply decisions, since it affects the purchasing power of the aftertax income the worker receives. The consumption tax varies from a low $7.6 \%$ in Switzerland, to a high $25 \%$ in Denmark and Sweden. The U.S. has the second lowest consumption tax among the countries in our dataset. To capture the joint effect of labor and consumption taxes, we consider the effective tax rate on labor income, $\tau$, as defined in Prescott (2004) is $\tau=1-\left(1-\tau_{l}\right) /\left(1+\tau_{c}\right)$, which is the fraction of labor income that is taken by the government in the form of labor and consumption taxes.

Table 3 shows the results of regressing (the log of) average annual hours of work on the number of divorces per 1000 married people and each of our tax measures. ${ }^{12}$ In Columns (3) and (4), we find that both the divorce rate and the average tax rate/average effective tax rate are highly statistically significant, and have the expected sign - higher taxes tend to reduce average hours worked, while higher number of divorces tends to increase them.

Fig. 1 shows that the taxes and divorces affect men and women differently. While there is a strong positive correlation between the divorce rates and hours worked for women, the corresponding correlation for men is positive but close to zero. On the other hand, while there is a strong negative correlation between the hours worked and the average effective tax rate for men, the corresponding correlation for women is also negative but close to zero.

This is further confirmed in Panel B of Table 3 where we regress (the logarithm of) hours worked on divorce rate and average effective tax rate for men and women separately.

\section{Model}

The stationary economy is populated by three types of households: single males, single females, and married couples. Individuals start their work life at age 20. They live for at least 65 years and at most 95 years, but enter retirement at age 65 . A model period is 1 year, so there are a total of 45 model periods of active work life. In addition to demographics, households are heterogeneous with respect to asset holdings, years of labor market experience, and idiosyncratic productivity shocks (market luck). Single households face an age-dependent probability of becoming married, while married couples face an age-dependent probability of divorce. One is more likely to be married to someone with a similar level of education. We assume that marriage will always happen to a partner of the same age, and that married couples die together. Households decide whether or not to participate in the labor market, how many hours to work conditional on participation, how much to consume, and how much to save. If they participate in the labor market, they accumulate one year of labor market experience.

\subsection{Labor income}

Individuals choose work hours, $n \in[0,1]$. The wage per time unit, $w$, of an individual depends on his level of education, $j \in\{$ hs, c $\}$ (where "hs" stands for high school and "c" stands for college), gender, $g \in\{\mathrm{m}, \mathrm{f}\}$, years of labor market experience, $x$, and idiosyncratic productivity shock, $u$ :

$$
\begin{aligned}
& w(j, g, x, u)=e^{\gamma_{0 j g}+\gamma_{1 j g} x+\gamma_{2 j g} x^{2}+\gamma_{3 j g} x^{3}+u} \\
& u^{\prime}=\rho_{j g} u+\epsilon, \quad \epsilon \sim N\left(0, \sigma_{j g}^{2}\right)
\end{aligned}
$$

Given this wage function, the beginning wage level as well as the returns to experience and idiosyncratic shock process are allowed to differ by level of education and gender. The productivity shock is assumed to follow the AR(1)-process in Eq. (5).

\footnotetext{
${ }^{11}$ An analogous measure is used in Caucutt et al. (2003).

${ }^{12}$ We provide the details of how we construct these divorce rates in the calibration section below.
} 
Table 3

Relation between average hours worked, divorce rates and tax measures.

\begin{tabular}{|c|c|c|c|c|}
\hline \multicolumn{5}{|c|}{ Panel A: Hours for both genders } \\
\hline & (1) & $(2)$ & (3) & (4) \\
\hline Divorce rate & $\begin{array}{l}0.026^{*} \\
(0.013)\end{array}$ & $\begin{array}{l}0.023^{*} \\
(0.012)\end{array}$ & $\begin{array}{l}0.039^{* * * *} \\
(0.011)\end{array}$ & $\begin{array}{l}0.038^{* * * *} \\
(0.011)\end{array}$ \\
\hline Top marginal tax rate & $\begin{array}{l}-0.004 \\
(0.004)\end{array}$ & - & - & - \\
\hline Progressivity wedge & - & $\begin{array}{l}-0.622 \\
(0.432)\end{array}$ & - & - \\
\hline $\begin{array}{l}\text { Average labor income } \\
\quad \operatorname{tax}\end{array}$ & - & - & $\begin{array}{l}-0.869^{* * * *} \\
(0.287)\end{array}$ & - \\
\hline Average effective tax rate & - & - & - & $\begin{array}{l}-0.913^{* * * *} \\
(0.264)\end{array}$ \\
\hline Const & $\begin{array}{l}7.117^{\text {***k }} \\
(0.189)\end{array}$ & $\begin{array}{l}7.057^{* * * *} \\
(0.113)\end{array}$ & $\begin{array}{l}7.113^{* * *} \\
(0.081)\end{array}$ & $\begin{array}{l}7.223^{* * * * *} \\
(0.099)\end{array}$ \\
\hline Adjusted $R^{2}$ & 0.142 & 0.184 & 0.423 & 0.484 \\
\hline \multicolumn{5}{|c|}{ Panel B: Average hours by gender } \\
\hline & \multicolumn{3}{|c|}{ Men } & Women \\
\hline \multicolumn{2}{|l|}{ Divorce rate } & \multicolumn{2}{|c|}{$\begin{array}{l}0.019^{*} \\
(0.009)\end{array}$} & $\begin{array}{l}0.070^{\text {****k }} \\
(0.019)\end{array}$ \\
\hline \multicolumn{2}{|l|}{ Average effective tax rate } & \multicolumn{2}{|c|}{$\begin{array}{l}-1.055^{\text {***k }} \\
(0.229)\end{array}$} & $\begin{array}{l}-0.710 \\
(0.474)\end{array}$ \\
\hline Const & \multicolumn{3}{|c|}{$\begin{array}{l}7.595^{* * * *} \\
(0.086)\end{array}$} & $\begin{array}{l}6.705^{* * * *} \\
(0.179)\end{array}$ \\
\hline \multicolumn{2}{|l|}{ Adjusted $R^{2}$} & \multicolumn{2}{|l|}{0.533} & 0.403 \\
\hline
\end{tabular}

Note: Panel A reports the results of regressing logarithm of average hours worked in each country in the dataset on a number of divorces per 1000 married persons and each tax measure for both genders together. Panel B reports the results of regressing logarithm of average hours worked on divorce rates and average effective tax rate by gender. Panel A Columns (3) and (4) show that both the divorce rate and the average tax rate/average effective tax rate are highly statistically significant, and have the expected sign - higher taxes tend to reduce average hours worked, while higher number of divorces tends to increase them. Panel B shows that for women, the divorce rates are statistically significant and have three times larger magnitude than for men. The average effective tax rates are highly statistically significant for men, but not for women.

Standard errors are in parentheses. Stars denote statistical significance $\left({ }^{* * *} p<0.01,{ }^{* *} p<0.05\right.$, and $* p<0.10$, respectively).

\subsection{Preferences}

The momentary utility function of single individuals, $U^{S}$, depends on work hours, $n \in[0,1]$, consumption, $c$, and gender, $g$ :

$$
U^{S}(g, c, n)=\log (c)-\chi_{g} \frac{n^{1+\eta_{g}}}{1+\eta_{g}}-F_{g} \rrbracket_{[n>0]}
$$

$F_{g}$ is a fixed, gender specific, disutility from working positive hours. The indicator function, $1_{[n>0]}$, is equal to 0 when $n=0$ and equal to 1 when $n>0 . \chi_{g}$ here captures the taste for work while $1 / \eta_{g}$ is the Frisch elasticity of labor supply conditional on employment. Married couples have a joint utility function, $U^{M}$, with shared consumption, measured in adult equivalents:

$$
U^{M}\left(c, n_{m}, n_{f}\right)=\log (c / e)-\chi_{m} \frac{n_{m}^{1+\eta_{m}}}{1+\eta_{m}}-\chi_{f} \frac{n_{f}^{1+\eta_{f}}}{1+\eta_{f}}-F_{m} \mathbb{1}_{\left[n_{m}>0\right]}-F_{f} \mathbb{1}_{\left[n_{f}>0\right]}
$$

\subsection{Marriage and divorce}

Marriages and divorces occur exogenously in the model. Single households face an age-dependent probability, $\bar{\omega}(t)$, of marriage whereas married households face an age-dependent probability, $\pi(t)$, of divorce. We assume that one is always 

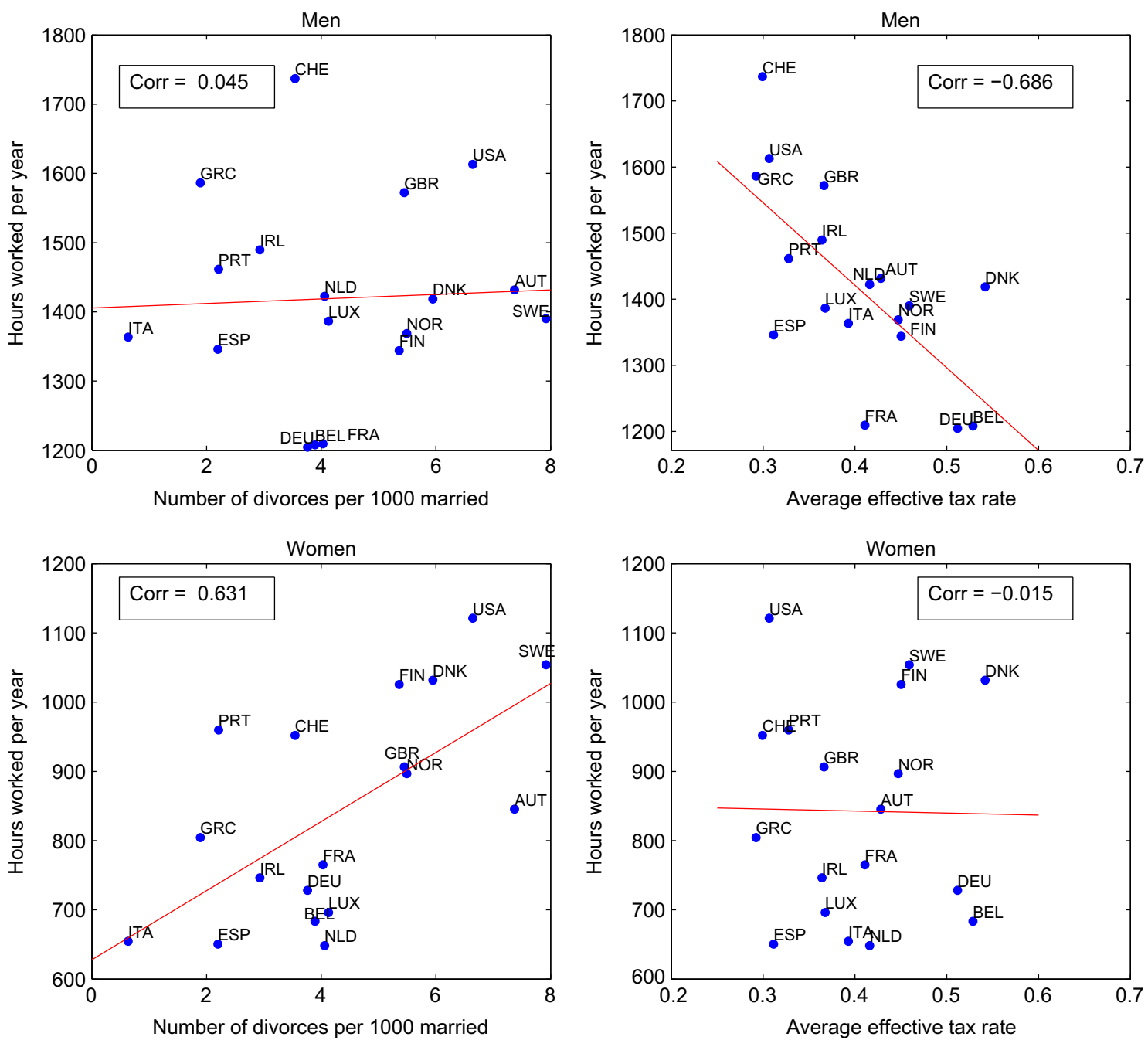

Fig. 1. Correlation between hours worked, divorce rates and tax rates for men and women. Note: This figure reports the correlation between hours worked per year, with divorce and tax rates by gender. There is a strong positive correlation between the divorce rates and hours worked for women. For men it is positive but close to zero. There is a strong negative correlation between the hours worked and the average effective tax rate for men. The corresponding correlation for women is also negative but close to zero.

married to someone of the same age and that married couples die together. Except for age, the only form of assortative mating in the model is by education. There is a higher probability, $\bar{\omega}_{\text {intra_ed. }}$, of marrying someone with the same level of education. Conditional on age, education and gender, a draw of partner is made from the distribution of singles generated by the model, $Q^{j g t}(j, x, k, u)$. This means that the agents in the model have rational expectations about their partner's education level, $j$, experience, $x$, asset holdings, $k$ and productivity shock, $u$.

\subsection{Government}

The government taxes consumption and labor income run a balanced budget. We assume that a fraction $(1-\vartheta)$ of the government revenues are wasted, i.e. spent on things that are not in the model. The remainder of the government's revenues is spent on social security payments, $\Psi_{g}$, transfers to unemployed people, $T$, and lump sum transfers to households, $G$. $G$ captures a wide range of government expenditure, from education and healthcare to social aid and disability insurance. It is beyond the scope of the paper to model these programs in great detail. It is, however, reasonable to assume that these programs are progressive in the idiosyncratic shock, $u$. We let $G(u)=\alpha_{u}\left(u_{\max }-u\right)$, where $u_{\max }$ is the highest realized value of $u .^{13}$ Similar assumptions about the progressivity of $G$ are made by Oh and Reis (2012) and McKay and Reis (2013), who study government transfer programs in greater detail. Let $Y^{S}(g, j, k, x, u, t)$ be the measure of single households over gender, $g$,

\footnotetext{
${ }^{13}$ We discretize the process for $u$ using the method developed by Tauchen (1986). $\alpha_{\mathrm{u}}$ is adjusted to balance the budget.
} 
education, $j$, assets, $k$, experience, $x$, productivity shock, $u$, and age, $t$, and $\gamma^{M}\left(j_{m}, j_{f}, k, x_{m}, x_{f}, u_{m}, u_{f}, t\right)$ be the measure of married households. The government budget can thus be written:

$$
\begin{aligned}
& \int G d Y^{S}+\int\left(G_{m}+G_{f}\right) d Y^{M}=\vartheta \int\left(n w \tau_{S}(w n)+c \tau_{c}\right) d Y^{S}+\vartheta \int\left(\left(n_{m} w_{m}+n_{f} w_{f}\right) \tau_{M}\left(n_{m} w_{m}+n_{f} w_{f}\right)+c \tau_{c}\right) d Y^{M} \\
& -\int\left(T \mathbb{1}_{[t \leq 44, n=0]}+\Psi_{g} \mathbb{1}_{[t>44]}\right) d Y_{g}^{S}-\int\left(T\left(\mathbb{1}_{\left[t \leq 64, n_{m}=0\right]}+\mathbb{1}_{\left[t \leq 64, n_{f}=0\right]}\right)\right) d \Upsilon^{M} \\
& -\int\left(\left(\Psi_{m}+\Psi_{f}\right) \mathbb{1}_{[t>44]}\right) d Y^{M}
\end{aligned}
$$

Eq. (8) says that the sum of lump sum payments to households is equal to the fraction of tax revenues that is not wasted minus expenses on social security and transfers to non-working households.

\subsection{Household's problem}

Let $r$ be the risk-free interest rate and $\beta$ the time discount factor. $\tau_{c}$ and $\tau_{k}$ represent flat taxes on consumption and capital, whereas $\tau_{S}$ and $\tau_{M}$ are nonlinear labor income taxes for singles and married couples, respectively. In most OECD countries, at least some part of the tax schedule is dependent on whether a person is single or married. There is, however, significant cross country variation. Written recursively, a single household's problem can be formalized as follows:

$$
\begin{gathered}
V^{S}(g, j, k, x, u, t)=\max _{c, n, k^{\prime}} U^{S}(g, c, n)+\beta\left((1-\bar{\omega}(t)) E_{u^{\prime}}\left[V^{S}\left(g, j, k^{\prime}, x^{\prime}, u^{\prime}, t+1\right)\right]\right. \\
\left.+\bar{\omega}(t) E_{j_{p}, k_{p}^{\prime}, x_{p}^{\prime}, u^{\prime}, u_{p}^{\prime}}\left[V^{M}\left(j, j_{p}, k^{\prime}+k_{p}^{\prime}, x^{\prime}, x_{p}^{\prime}, u^{\prime}, u_{p}^{\prime}, t+1\right)\right]\right) \\
\text { s.t. : } \quad \begin{aligned}
c\left(1+\tau_{c}\right)+k^{\prime}= & k\left(1+r\left(1-\tau_{k}\right)\right)+n w(j, g, x, u)\left(1-\tau_{S}(w(j, g, x, u) n)\right) \\
& +G(u)+\left(1-\mathbb{1}_{[n>0]}\right) T
\end{aligned} \\
x^{\prime}=x+1_{[n>0], \quad} \quad n \in[0,1], \quad k^{\prime} \geq 0, \quad c>0,
\end{gathered}
$$

The subscript, $p$, stands for partner. In the case that an individual becomes married in the next period, the expectation of next period's utility must be taken with respect to the distribution over potential partners' education, experience, asset holdings, and idiosyncratic productivity shock, $Q^{j g t}\left(j_{p}, x_{p}^{\prime}, k_{p}^{\prime}, u_{p}\right) .{ }^{14}$ Married couples maximize their joint utility and face an age-dependent probability, $\pi(t)$, of becoming divorced. When couples divorce, they split their assets evenly. Their problem can be written as

$$
\begin{aligned}
& V^{M}\left(j_{m}, j_{f}, k, x_{m}, x_{f}, u_{m}, u_{f}, t\right)=\max _{c, k^{\prime}, n_{m}, n_{f}} U^{M}\left(c, n_{m}, n_{f}\right) \\
& \quad+\beta(1-\pi(t)) E_{u_{m}^{\prime}, u_{f}^{\prime}}\left[V^{M}\left(j_{m}, j_{f}, k^{\prime}, x_{m}^{\prime}, x_{f}^{\prime}, u_{m}^{\prime}, u_{f}^{\prime}, t+1\right)\right] \\
& \quad+\beta \pi(t) E_{u_{m}^{\prime}}\left[V^{S}\left(m, k^{\prime} / 2, x_{m}^{\prime}, u_{m}^{\prime}, t+1\right)\right] \\
& \quad+\beta \pi(t) E_{u_{f}^{\prime}}\left[V^{S}\left(f, k^{\prime} / 2, x_{f}^{\prime}, u_{f}^{\prime}, t+1\right)\right] \\
& \quad \text { s.t }: \quad c\left(1+\tau_{c}\right)+k^{\prime}=k\left(1+r\left(1-\tau_{k}\right)\right)+\left(n_{m} w_{m}+n_{f} w_{f}\right)\left(1-\tau_{M}\left(n_{m} w_{m}, n_{f} w_{f}\right)\right) \\
& \quad+G\left(u_{m}\right)+G\left(u_{f}\right)+\left(2-\left(\mathbb{1}_{\left[n_{m}>0\right]}+\mathbb{1}_{\left[n_{f}>0\right]}\right) T\right. \\
& \quad x_{m}^{\prime}=x_{m}+\mathbb{1}_{\left[n_{m}>0\right]}, \quad x_{f}^{\prime}=x_{f}+\mathbb{1}_{\left[n_{f}>0\right]}, n_{f}, n_{m} \in[0,1], \quad k^{\prime} \geq 0, \quad c>0
\end{aligned}
$$

Retired households make no labor supply decisions but receive an amount of social security, $\Psi_{g}$, depending on their gender. We assume that retirees receive a lump sum redistribution equal to a working individual with a 0 shock. We also assume that retired households do not marry or get divorced, and that husband and wife die at the same time. Their problem, if single, is simply:

$$
\begin{gathered}
V^{S}(g, k, t)=\max _{c>0, k^{\prime} \geq 0} U^{S}(g, c)+\Omega(t) \beta V^{S}\left(g, k^{\prime}, t+1\right) \\
\text { s.t. : } \quad c\left(1+\tau_{c}\right)=k\left(1+r\left(1-\tau_{k}\right)\right)+\Psi_{g}+G(u=0)
\end{gathered}
$$

where $\Omega(t)$ is the probability of survival until the next period. Married retirees solve

$$
\begin{aligned}
V^{M}(k, t)= & \max _{c>0, k^{\prime} \geq 0} U^{M}(c)+\Omega(t) \beta V^{M}\left(g, k^{\prime}, t+1\right), \\
\text { s.t. : } & c\left(1+\tau_{c}\right)=k\left(1+r\left(1-\tau_{k}\right)\right)+\Psi_{m}+\Psi_{f}+2 G(u=0)
\end{aligned}
$$

\footnotetext{
${ }^{14} Q^{j g t}$ and $Y^{S}$ are related as follows. Let the single person $i$ have gender $g_{i}$, age $t_{i}$ and education level $j_{i}$. Then:

$Q^{j_{i} q_{i} t_{i}}(j, x, k, u)=\bar{\omega}_{\text {intra_ed }} Y^{S}\left(-g_{i}, j_{i}, k, x, u, t_{i}\right)+\left(1-\bar{\omega}_{\text {intra_ed }}\right) Y^{S}\left(-g_{i},-j_{i}, k, x, u, t_{i}\right)$,

where $-g_{i}$ denotes the gender opposite to $g_{i}$, and $-j_{i}$ denotes the education level different from $j_{i}$.
} 


\section{Calibration}

We try to use data from 2000 or the year closest to 2000 that we can obtain. The reason for this is that for the year 2000 , we have data that can be used to construct divorce and marriage probabilities for all the countries in Western Europe. We also have tax data for all the countries starting in 2001.

\subsection{Preferences}

The momentary utility functions for single and married persons are given in Eqs. (6) and (7), with consumption measured in adult equivalents, $c / e$. We use the OECD adult equivalence scale and set $e=1.7$ for married couples, and $e=1.0$ for singles. The discount factor, $\beta$, the fixed costs of working, $F_{m}$ and $F_{f}$, as well as $\chi_{m}$ and $\chi_{f}$ are among the estimated parameters. The corresponding data moments are the mean asset holdings of individuals in households with head aged 20-64, taken from the PSID (99-05), male and female employment rates from the CPS (2000) and work hours, taken from OECD 2000.

There is considerable debate in the economic literature about the inter-temporal elasticity of labor supply, see Keane (2011) for a thorough survey. However, there seems to be a consensus that the elasticity of labor supply for women is larger than that for men. In our model, the inter-temporal elasticity will be related to both the fixed costs of working, $F_{m}$ and $F_{f}$, and the parameters $\eta_{m}$ and $\eta_{f}$. We chose to fix the latter two and calibrate the first two within the model. This ensures that the model matches both the intensive and extensive margin of labor supply for men and women. Another reason is that $\eta$ parameters have direct empirical counterparts in the intensive margin inter-temporal elasticity of labor supply. Kimmel and Kniesner (1998) separately estimate the intensive margin elasticities, corresponding to $1 / \eta_{m}$ and $1 / \eta_{f}$ in the model by controlling for selection and includes a fixed cost of participation. They obtain 0.39 for men and 0.66 for women. We choose to be slightly more conservative and set $1 / \eta_{m}=0.3,1 / \eta_{f}=0.6{ }^{15}$

\subsection{Risk free interest rate}

Given the partial equilibrium nature of the model, we take the risk free rate as fixed and calibrate it using the data. We set the risk free rate equal to the average of 3-month t-bill rates minus inflation over the period from 1947 to 2008 based on data from the Federal Reserve Bank of St. Louis.

\subsection{Wages}

We estimate the experience profile of wages and the processes for the idiosyncratic shocks exogenously, using the PSID from 1968 to 1997. After 1997, it is not possible to get years of actual labor market experience from the PSID. Appendix C describes the estimation procedure in more detail. We use a maximum likelihood approach to control for selection into the labor market, as described in Heckman (1976, 1979). We estimate different returns to experience for each gender/education group. We then obtain the residuals from these estimations and use the panel data structure of the PSID to estimate the parameters for productivity shock process $\rho_{j g}$ and $\sigma_{j g}$ by OLS. Our results for the shock processes are in line with Chang and Kim (2006) who use a similar approach on PSID data. To get levels of earnings that are in line with the asset holdings, we include a parameter controlling the average earnings of each gender/education group in the simulated moments estimation. The corresponding data moments are the average wage of each group in the PSID 99-05.

\subsection{Taxes}

For single households we use the labor income tax schedule proposed by Benabou (2002) and recently used in Heathcote et al. (2014). For married couples, we modify the tax function to distinguish between joint and separate taxation of their income. The tax schedule is then a function of an individual's (or each of the spouses') earnings relative to the average earnings (AE) (see Eqs. D.1 and D.2 in Appendix D). As described in more detail in the Appendix, we fit this function to labor income tax data from the OECD tax database (2001). This data is constructed by the OECD based on tax laws from different countries. It is well suited for cross country comparisons, see also Guvenen et al. (2014). We fit a different tax schedule for married and single individuals.

Coming up with an accurate estimate of consumption taxes in the U.S. is complicated by the fact that there are local county-level taxes in addition to state taxes. Vertex Inc. (a consulting company) estimated that the average consumption tax in the U.S. was $8.4 \%$ in 2002. We use that number. We follow Trabandt and Uhlig (2011) and set $\tau_{k}=36 \%$.

\subsection{Death probabilities and social security}

We obtain the probability that a retiree will survive to the next period from the National Center for Health Statistics (1991-2001). We assume that all retirees receive the same constant Social Security benefit, which only depends on gender.

\footnotetext{
${ }^{15}$ A calibration where we set the elasticity of labor supply of both genders equal to each other, $1 / \eta_{m}=1 / \eta_{f}=0.4$, yields similar results.
} 
We obtain the average benefit for males and females from the Annual Statistical Supplement to the Social Security Bulletin (2000).

\subsection{Marriage and divorce probabilities}

To compute the age-specific probabilities for marriage and divorce for the U.S., we use the data from the CPS March supplement from 1999 to 2001. For most European countries, we use the data from Eurostat on-line database. For some European countries, we supplement it with the data from the IPUMS International.

We assume a stationary environment, where the probabilities of getting married and divorced do not change over time (we allow them to depend on the age of the person, but not on his/her cohort). We also assume that the probability of getting married is the same for those who get married for the first time, and those who were previously divorced. This allows us to compute the probabilities using the following approach. Let $M_{t}$ and $D_{t}$ be the share of the married and divorced persons respectively at age $t$. Then the probability of getting married at age $t, \bar{\omega}(t)$, and the probability of getting divorced at age $t, \pi(t)$, is pinned down by

$$
\begin{aligned}
& M_{t+1}=\left(1-M_{t}\right) \bar{\omega}(t)+M_{t}(1-\pi(t)) \\
& D_{t+1}=D_{t}(1-\bar{\omega}(t))+M_{t} \pi(t)
\end{aligned}
$$

We smooth the resulting age-profiles for $\bar{\omega}(t)$ and $\pi(t)$ by fitting a polynomial. We find that the probability of getting divorced is noticeably higher in the U.S. compared to Italy, and somewhat higher compared to Germany. At the same time, the probability of getting married reaches its peak in the U.S. somewhat earlier compared to the two European countries. ${ }^{16}$

\subsection{Transfers to unemployed, fixed cost of working and lump sum redistribution}

People who do not work have other source of income such as unemployment benefits, gifts from relatives and charities, black market work, etc. They also have more time for home production (not included in the model). Pinning down the money equivalent value of not working is a difficult task. The number we choose will also affect the size of the fixed cost of working, which we calibrate endogenously to hit the employment rates for men and women, see Panel B of Table H.13 in the Appendix. As an approximation for income when not working, we take the average value of non-housing consumption of households with income less than $\$ 5000$ per year from the 2000-2001 Consumer Expenditure Survey. As pointed out by Oh and Reis (2012) transfers to households make up a majority of the government's expenditure. To determine $\vartheta$, the fraction of the government's income, which can be spent on households in the model, we take the U.S. government budget from 2000 and remove expenditures on defense, interest payments and protection. This leaves us with $76 \%$ of the year 2000 government budget. The corresponding average value of $G$ in the model is then $\$ 2200$. As described in the model section, $G$ is, however, decreasing in the idiosyncratic shock, $G=\alpha_{u}\left(u_{\max }-u\right){ }^{17}$

We also consider an alternative, country-specific calibration of the government transfers, where we use the idea from Piketty and Saez (2012), and collect the data on: (1) total public spending; (2) social public spending that consists of 5 major categories - (a) education, (b) health, (c) pensions, (d) income support to working age, (e) other social public spending for all countries in our sample for the year 2000. We use the data from Adema et al. (2011) and OECD (2011), which we summarize in the Appendix in Table G.9. We assume that all public spending that does not fall in one of the "social public spending" subcategories is wasteful from the point of view of the model agents. We assume that "income support to the working age" and "other social public spending" (which according to Piketty and Saez (2012) include social services to the elderly and the disabled, family services, housing and other social policy areas) are lump-sum transfers to the poor, while education and health spending are lump-sum transfers to all agents. ${ }^{18}$

\subsection{Calibration method}

The nine parameters which must be calibrated inside the model are found by minimizing the distance between simulated model moments and data moments. Panel B of Table H.13 in the Appendix summarizes the nine calibrated parameter values and the data moments. We are able to match all the moments exactly.

\subsection{Model fit}

It is natural to ask how the model performs along some dimensions, which has not been explicitly targeted. The model does quite well along a number of dimensions. The standard deviation of log earnings is for instance 0.650 compared to

\footnotetext{
${ }^{16}$ The computed probabilities use the data for women. We get a qualitatively similar picture when using the data for both men and women (with the exception that men in all countries tend to get married somewhat later than women).

${ }^{17}$ The value of $\alpha_{\mathrm{u}}$ is determined by the level of lumpsum redistribution. In the benchmark model its value is 0.043 .

18 Piketty and Saez (2012) argue that education and health care government spending are approximately a transfer of equal value for all individuals in expectation over a lifetime.
} 
a
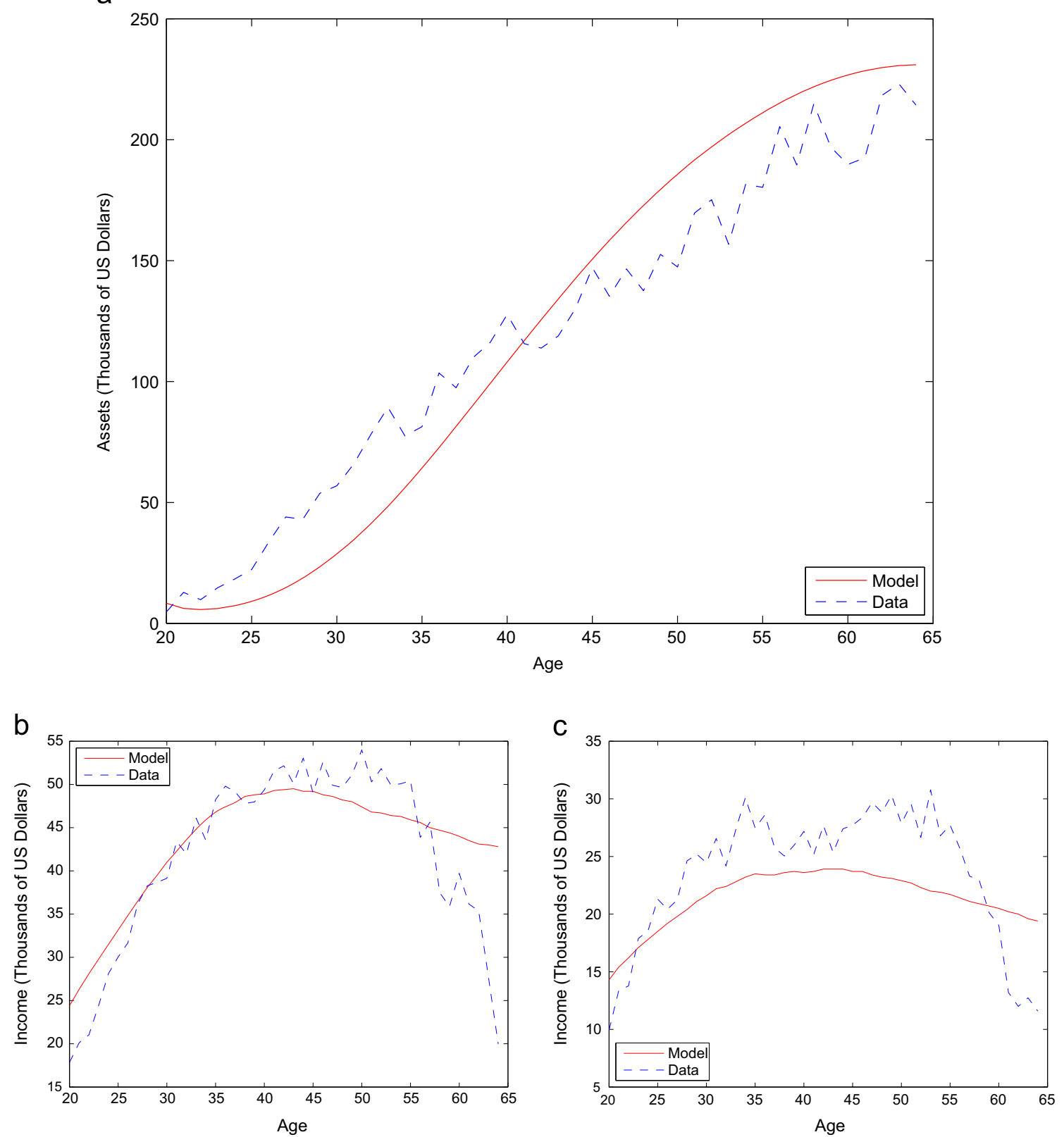

Fig. 2. Model fit: assets and income over the life-cycle. (a) Assets over the life cycle, (b) male income over the life cycle and (c) female income over life cycle. Note: The figure plots the life-cycle profiles of asset holdings and earnings by gender in the model and data.

0.661 in the data. In Fig. 2, we plot the life-cycle profiles of asset holdings and earnings by gender in the model and data. The model does quite well in matching the life-cycle profiles of earnings and asset holdings in the data. The reason that average earnings for women is a bit lower in the model than in the data is that the earnings data is from the PSID, whereas the model was calibrated using wages from the PSID and hours worked from the CPS (female labor supply is a bit lower in the CPS). The model cannot replicate the hump shape in work hours over the life-cycle observed in the data.

The simulated Hicksian labor supply elasticity for our model is about 0.41 . This is in line with a survey of empirical studies in Keane (2011), where the average Hicksian elasticity estimate for 22 studies on males is equal to 0.31 . Our economy is, however, also inhabited by women who are known to have more elastic labor supply. The elasticity of female work hours with respect to the probability of divorce is somewhat smaller than the results in Johnson and Skinner (1986). They estimate that a $1 \%$ increase in divorce probability over a 6 -year period leads to a $1.3 \%$ increase in female labor supply. The corresponding number in our model is $0.71 \%$. 


\section{The impact of marriage stability and taxation on labor supply}

We consider three different counterfactual experiments: (i) we replace both the U.S. marriage and divorce probabilities, and the tax system in the model with the ones we compute for each European country in our sample; (ii) we replace only the marriage and divorce probabilities, and leave the tax system unchanged, at the U.S. level; (iii) we replace only the tax system, and leave the marriage and divorce probabilities unchanged, at their U.S. values.

During these experiments, we keep taxes, old age social security, and income when not working proportional to the average earnings in the economy. ${ }^{19}$ In this way, if the society becomes richer or poorer because of a counterfactual experiment, taxes and social security payments will adjust accordingly.

\subsection{The effect of marriage stability and taxation}

Fig. 3 shows the results when simultaneously replacing both the U.S. marriage and divorce probabilities and the tax system in the model with those obtained for each European country. On the horizontal axis, we put hours worked in each country relative to the U.S. (in percent) in the data, while on the vertical axis, we put hours worked relative to the U.S. (also in percent) in the model.

Ideally, if the model were able to match the hours worked in the European countries exactly, using just the two mechanisms that we study in this paper, all the observations would fall on the diagonal line (the black line). If the observation for a particular European country falls to the left of the diagonal line in the picture, it means that the two mechanisms that we study do not lead to enough reduction of hours worked in that country compared to the U.S. to match the data perfectly (agents "work too much" in the model compared to the data), and vice versa if the observation falls to the right of the diagonal. Hours worked in the U.S. fall on the diagonal line by construction, since our model is calibrated to match the U.S. in terms of annual hours worked.

Fig. 3 shows that we obtain a positive correlation between the hours worked generated by the model and hours worked that we find in the data, equal to 0.327 . We explain $45 \%$ of the variation between the U.S. and the European countries in the data as measured by the coefficient of determination:

$$
R^{2}=1-\frac{\mathrm{SS}_{\text {err }}}{\mathrm{SS}_{\text {tot }}}
$$

where $\mathrm{SS}_{\text {err }}=\sum_{i=1}^{n}\left(h_{i, \text { model }}-h_{i \text {,data }}\right)^{2}, \mathrm{SS}_{\text {tot }}=\sum_{i=1}^{n}\left(h_{i, \text { data }}-h_{u s}\right)^{2}, h_{i, \text { model }}$ is the hours worked in country $i$ generated by the model, $h_{i, \text { data }}$ is the hours worked in country $i$ in the data, and $h_{u s}$ is the hours worked in the U.S. (both in the model and in the data). ${ }^{20}$ This means that the two mechanisms that we study work in the right direction. However, since all our European countries but Denmark fall to the left of the diagonal, this means that the two mechanisms that we study generally do not reduce the hours worked in the model enough to match the data perfectly.

Column (3) of Table 4 lists the results for each country in the model, as percent of hours worked in the U.S., next to the observed value in the data in Column (2). As can be seen from the table, we are relatively more successful in explaining hours worked in the Nordic countries and Central Europe than in Southern Europe.

Panels (b) and (c) of Fig. 3 illustrate the impact of one mechanism at a time - we either change the U.S. marriage and divorce probabilities in the model to those found in the European countries while keeping the tax system unchanged (i.e. set to the U.S. level), or change the U.S. tax system while keeping the marriage and divorce probabilities unchanged. In both cases, we get positive correlations between the hours worked generated in the model and those that we find in the data higher taxes and higher marriage stability reduce hours worked in the model. The correlations with the data in both separate experiments are of about equal strength, and smaller than those from the combined experiment, suggesting that both mechanisms play an important role in accounting for the difference in hours worked between the U.S. and Europe (which is similar to what we found in Section 3). As measured by $R^{2}$, divorce and marriage probabilities explain $17 \%$ of the variation in labor supply between the U.S. and the European countries, whereas taxes explain 32\%.

As can be seen from Columns (4) and (5) in Table 4, taxes generally work in the wrong direction for the Southern European countries, which have low taxes, and hours increase relative to the United States. However, Southern European countries have very low divorce rates, which work in the right direction for these countries. In the Nordic countries divorce and marriage probabilities work in the wrong direction. These countries have very low marriage rates and also high divorce rates. Taxes, however, do a good job of predicting labor supply in the Nordic countries. In Central Europe both the divorce and tax mechanisms reduce hours relative to the U.S.

Table 5 shows the results from the alternative, country-specific calibration of the government transfers. In this alternative calibration, when we replace both the marriage and divorce probabilities and the tax system from the European countries, we explain $47.5 \%$ of the variation in hours worked between the U.S. and the European countries, as measured by $R^{2}$.

\footnotetext{
${ }^{19}$ In the case of taxes, we have specified them as polynomials in $y / \mathrm{AE}$, where $y$ is individual labor income, and AE is the average earnings in the economy.

${ }^{20}$ In the literature our $R^{2}$ is also referred to as the "forecast skill" measure. It evaluates by how much the model in question improves the forecast compared to some reference model. In our case, the hours worked in the U.S. are used as the "reference model".
} 
a

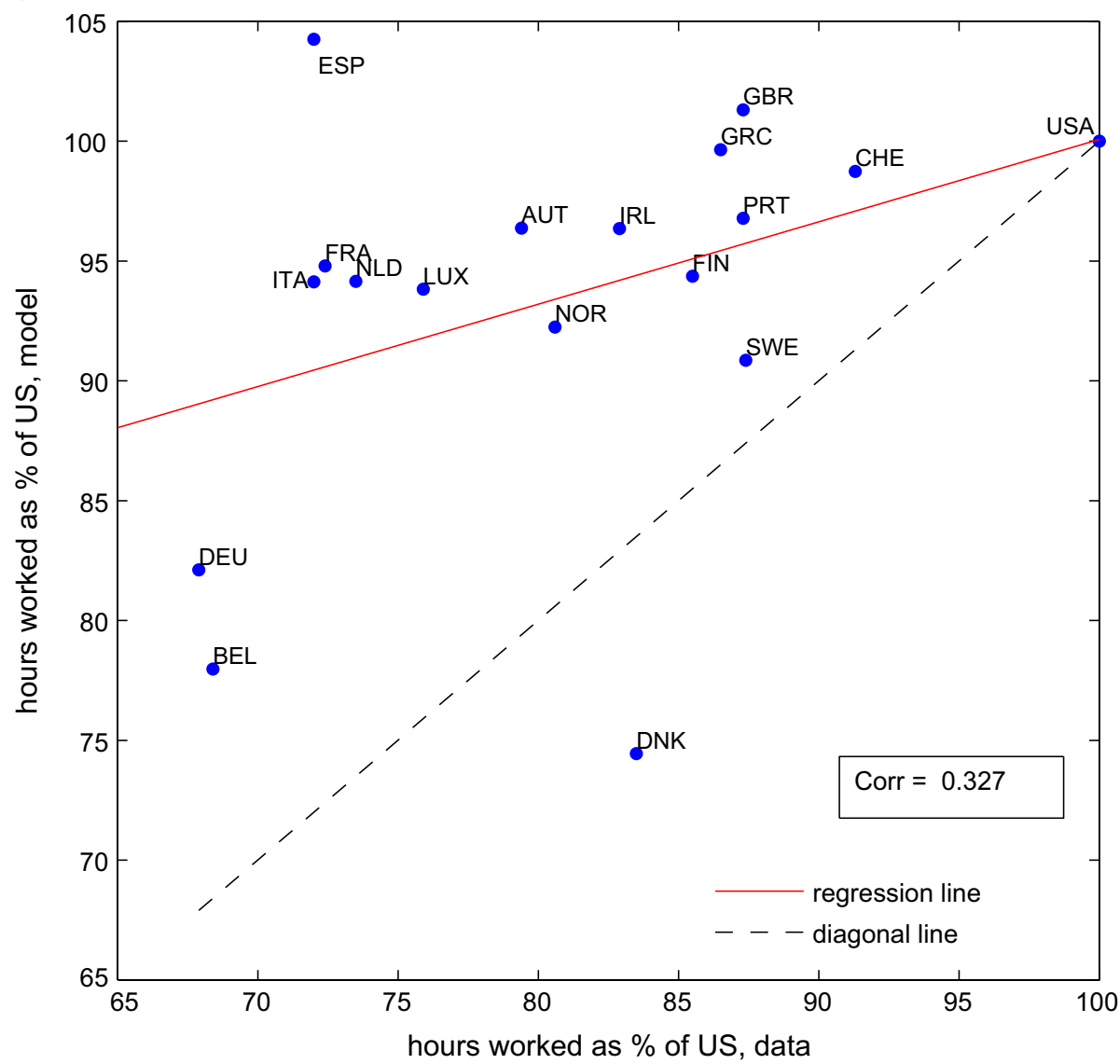

b

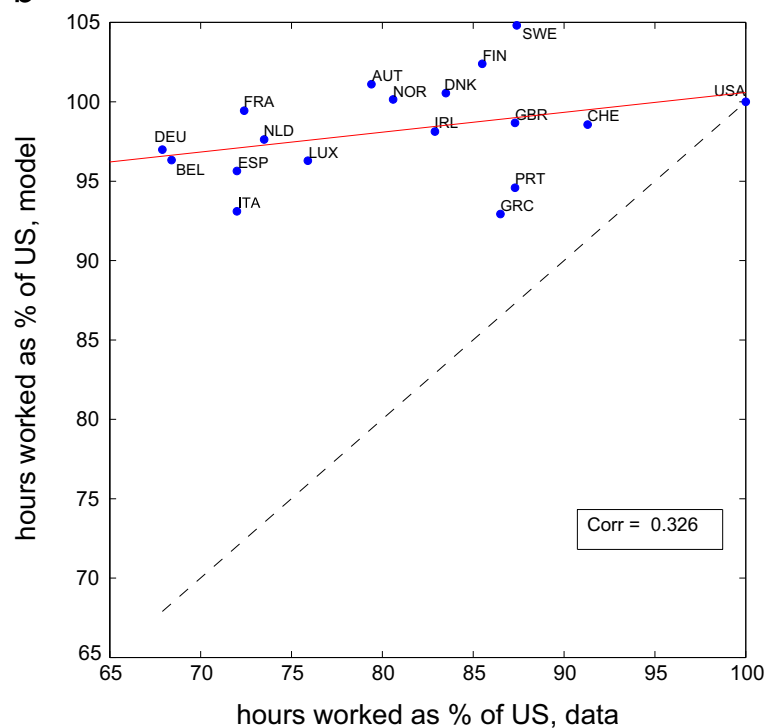

C

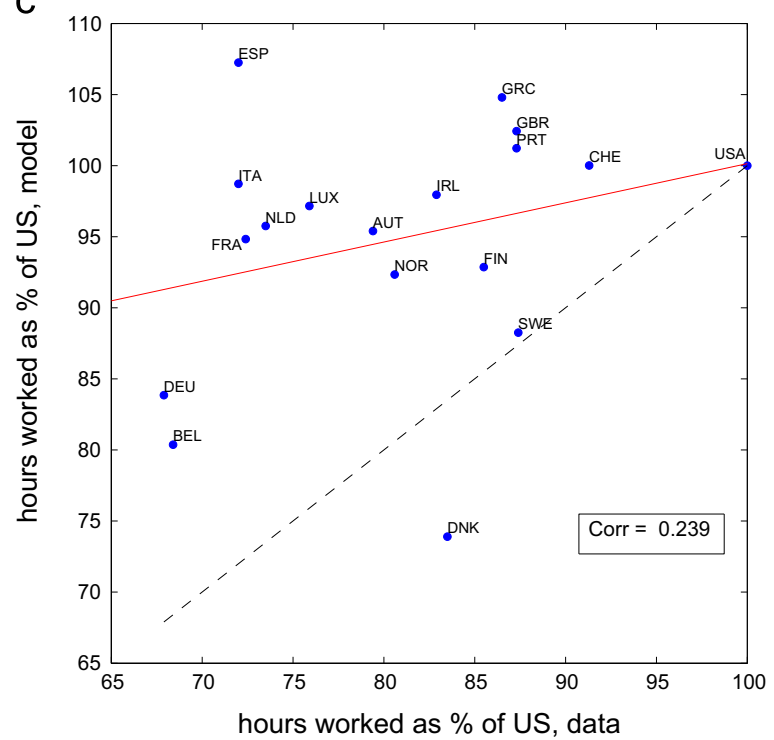

Fig. 3. Combined and separate effect of marriage stability and taxes. (a) Combined effect of marriage stability and taxes, (b) effect of marriage stability, (c) effect of taxes. Note: This figure reports the results when simultaneously replacing both the U.S. marriage and divorce probabilities and the tax system in the model with those obtained for each European country. The horizontal axis represents hours worked in each country relative to the U.S. (in percent) in the data. The vertical axis represents hours worked relative to the U.S. (in percent) in the model. 
Table 4

Hours worked in the model and in the data, in percent of the U.S. hours.

\begin{tabular}{|c|c|c|c|c|c|c|c|c|c|c|c|c|}
\hline \multirow[b]{2}{*}{ (1) } & \multicolumn{4}{|l|}{ All } & \multicolumn{4}{|l|}{ Men } & \multicolumn{4}{|c|}{ Women } \\
\hline & $\begin{array}{l}\text { Data } \\
(2)\end{array}$ & $\begin{array}{l}\text { Tax. \& Div. } \\
\text { (3) }\end{array}$ & $\begin{array}{l}\text { Divorces } \\
(4)\end{array}$ & $\begin{array}{l}\text { Taxes } \\
\text { (5) }\end{array}$ & $\begin{array}{l}\text { Data } \\
(6)\end{array}$ & $\begin{array}{l}\text { Tax. \& Div. } \\
\text { (7) }\end{array}$ & $\begin{array}{l}\text { Divorces } \\
(8)\end{array}$ & $\begin{array}{l}\text { Taxes } \\
(9)\end{array}$ & $\begin{array}{l}\text { Data } \\
(10)\end{array}$ & $\begin{array}{l}\text { Tax. \& Div. } \\
\text { (11) }\end{array}$ & $\begin{array}{l}\text { Divorces } \\
(12)\end{array}$ & $\begin{array}{l}\text { Taxes } \\
(13)\end{array}$ \\
\hline \multicolumn{13}{|c|}{ Nordic countries: } \\
\hline Denmark & 83.5 & 74.4 & 100.5 & 73.9 & 82.3 & 70.9 & 100.5 & 70.3 & 86.9 & 79.7 & 100.6 & 79.1 \\
\hline Finland & 85.5 & 94.4 & 102.4 & 92.9 & 81.3 & 87.3 & 100.6 & 86.4 & 90.6 & 104.6 & 105.0 & 102.2 \\
\hline Norway & 80.6 & 92.2 & 100.1 & 92.3 & 81.7 & 87.1 & 99.9 & 87.3 & 77.7 & 99.7 & 100.5 & 99.7 \\
\hline Sweden & 87.4 & 90.9 & 104.8 & 88.3 & 83.7 & 85.5 & 102.7 & 84.1 & 91.9 & 98.7 & 107.9 & 94.2 \\
\hline Mean: & 84.3 & 88.0 & 102.0 & 86.8 & 82.3 & 82.7 & 100.9 & 82.0 & 86.8 & 95.7 & 103.5 & 93.8 \\
\hline \multicolumn{13}{|c|}{ Central Europe: } \\
\hline Austria & 79.4 & 96.4 & 101.1 & 95.4 & 84.6 & 92.0 & 100.9 & 91.2 & 71.8 & 102.8 & 101.5 & 101.6 \\
\hline Belgium & 68.4 & 78.0 & 96.3 & 80.4 & 73.9 & 73.8 & 97.8 & 75.6 & 60.5 & 84.0 & 94.3 & 87.3 \\
\hline Netherlands & 73.5 & 94.1 & 97.6 & 95.8 & 85.4 & 89.6 & 98.4 & 90.8 & 55.5 & 100.8 & 96.6 & 102.9 \\
\hline Germany & 67.9 & 82.1 & 97.0 & 83.8 & 71.3 & 86.2 & 98.0 & 87.3 & 62.1 & 76.2 & 95.5 & 78.8 \\
\hline Switzerland & 91.3 & 98.7 & 98.6 & 100.0 & 101.3 & 99.3 & 99.1 & 100.1 & 79.4 & 97.9 & 97.8 & 99.8 \\
\hline France & 72.4 & 94.8 & 99.4 & 94.8 & 75.0 & 94.0 & 99.2 & 94.2 & 68.8 & 96.0 & 99.8 & 95.8 \\
\hline Luxembourg & 75.9 & 93.8 & 96.3 & 97.2 & 85.1 & 95.5 & 98.0 & 96.9 & 61.4 & 91.5 & 93.8 & 97.5 \\
\hline UK & 87.3 & 101.3 & 98.7 & 102.4 & 94.5 & 97.5 & 98.9 & 98.5 & 77.9 & 106.9 & 98.3 & 108.1 \\
\hline Mean: & 77.0 & 92.4 & 98.1 & 93.7 & 83.9 & 91.0 & 98.8 & 91.8 & 67.2 & 94.5 & 97.2 & 96.5 \\
\hline \multicolumn{13}{|c|}{ Southern Europe: } \\
\hline Greece & 86.5 & 99.6 & 92.9 & 104.8 & 97.3 & 96.0 & 95.9 & 100.2 & 71.6 & 104.9 & 88.6 & 111.5 \\
\hline Ireland & 82.9 & 96.4 & 98.1 & 97.9 & 93.0 & 96.3 & 98.5 & 97.8 & 67.2 & 96.4 & 97.5 & 98.1 \\
\hline Italy & 72.0 & 94.1 & 93.1 & 98.7 & 82.3 & 89.6 & 95.8 & 93.2 & 57.3 & 100.7 & 89.1 & 106.8 \\
\hline Portugal & 87.3 & 96.8 & 94.6 & 101.2 & 88.9 & 97.7 & 97.0 & 100.3 & 84.9 & 95.4 & 91.0 & 102.6 \\
\hline Spain & 72.0 & 104.2 & 95.6 & 107.2 & 99.8 & 99.7 & 97.2 & 102.3 & 57.4 & 110.8 & 93.5 & 114.4 \\
\hline Mean: & 80.1 & 98.2 & 94.9 & 102.0 & 92.3 & 95.9 & 96.9 & 98.8 & 67.7 & 101.7 & 91.9 & 106.7 \\
\hline U.S.A. & 100.0 & 100.0 & 100.0 & 100.0 & 100.0 & 100.0 & 100.0 & 100.0 & 100.0 & 100.0 & 100.0 & 100.0 \\
\hline$R^{2}$ & & 0.452 & 0.170 & 0.321 & & 0.757 & 0.090 & 0.708 & & 0.098 & 0.217 & -0.066 \\
\hline $\begin{array}{l}\text { Corr (data, } \\
\text { model) }\end{array}$ & & 0.327 & 0.326 & 0.239 & & 0.671 & -0.219 & 0.680 & & 0.040 & 0.614 & -0.140 \\
\hline
\end{tabular}

Note: This table displays hours worked as \% of U.S. hours in the data and in the model, after introducing taxes and divorce and marriage rates from other countries. Column (2) reports data and Column (3) reports the results when we simultaneously replace both the U.S. marriage and divorce probabilities and the tax system in the calibrated model with those obtained for each European country. Columns (4) and (5) respectively report results when we replace only the marriage and divorce probabilities, and leave the tax system unchanged, at the U.S. level; and when we replace only the tax system, and leave the marriage and divorce probabilities unchanged, at their U.S. values. Columns (6)-(13) repeat the exercise by gender. Overall the model explains $45 \%$ of the variation in labor supply between the U.S. and the European countries, as measured by $R^{2}$.

\subsection{The effect on men and women separately}

Fig. 4 and Columns (6)-(13) of Table 4 present the results. The figure shows that there is a very pronounced difference in how these two mechanisms affect men and women in our model. Female labor supply is mostly correlated with the marriage stability mechanism. Female hours worked fall in countries with more stable marriages. At the same time, in the model where we only change the tax system, leaving the marriage and divorce probabilities at their U.S. levels, the correlation between the actual hours worked by women in the data and those generated by our model is small and negative. As measured by $R^{2}$, divorce and marriage probabilities explain $22 \%$ of the variation in female labor supply between the U.S. and the European countries, while taxes do not help to explain the differences in hours worked in our model.

The results for men are directly opposite to those for women. In our model, men appear to react mostly to the changes in the tax system. When we change the marriage and divorce probabilities and leave the taxes at their U.S. levels, the correlation between the actual hours worked by men in the data and those generated by our model is small and negative. This is in line with our findings in Section 2 that there is no correlation between male labor supply and divorce rates in the data. The $R^{2}$ for men is $9 \%$ when we introduce European marriage and divorce probabilities and $71 \%$ when we introduce European tax systems into the model. We conclude that taxes are a very powerful explanation for male labor supply, while divorce and marriage rates help significantly in explaining female labor supply.

\subsection{The impact of tax progressivity and separate taxation on male and female labor supply}

Why do the higher European taxes affect men much more than women in our model? The effect is related to the structure of the tax systems. The European countries with high average labor income taxes are also more likely to have higher tax progressivity (the correlation between the average effective labor income tax rate and the tax progressivity measure that we used in Section 3 is for instance 0.389 is our sample), meaning that the higher tax rates in these countries 
Table 5

Hours worked in the model and in the data, in percent of the U.S. Hours: alternative calibration of government transfers.

\begin{tabular}{|c|c|c|c|c|c|c|}
\hline \multirow[b]{2}{*}{ (1) } & \multicolumn{2}{|l|}{ All } & \multicolumn{2}{|l|}{ Men } & \multicolumn{2}{|c|}{ Women } \\
\hline & $\begin{array}{l}\text { Data } \\
(2)\end{array}$ & $\begin{array}{l}\text { Model } \\
\text { (3) }\end{array}$ & $\begin{array}{l}\text { Data } \\
(4)\end{array}$ & $\begin{array}{l}\text { Model } \\
\text { (5) }\end{array}$ & $\begin{array}{l}\text { Data } \\
(6)\end{array}$ & $\begin{array}{l}\text { Model } \\
(7)\end{array}$ \\
\hline \multicolumn{7}{|l|}{ Nordic countries: } \\
\hline Denmark & 83.5 & 75.1 & 82.3 & 71.7 & 86.9 & 80.1 \\
\hline Finland & 85.5 & 94.0 & 81.3 & 86.9 & 90.6 & 104.4 \\
\hline Norway & 80.6 & 90.1 & 81.7 & 84.9 & 77.7 & 97.6 \\
\hline Sweden & 87.4 & 89.8 & 83.7 & 84.6 & 91.9 & 97.5 \\
\hline Mean: & 87.3 & 82.0 & 94.9 & 84.2 & 82.2 & 86.8 \\
\hline \multicolumn{7}{|l|}{ Southern Europe: } \\
\hline Greece & 86.5 & 101.8 & 97.3 & 98.2 & 71.6 & 107.0 \\
\hline Ireland & 82.9 & 96.7 & 93.0 & 96.6 & 67.2 & 97.0 \\
\hline Italy & 72.0 & 94.4 & 82.3 & 89.9 & 57.3 & 100.8 \\
\hline Portugal & 87.3 & 96.6 & 88.9 & 97.5 & 84.9 & 95.2 \\
\hline Spain & 72.0 & 102.7 & 99.8 & 98.2 & 57.4 & 109.3 \\
\hline Mean: & 98.4 & 96.1 & 101.9 & 80.1 & 92.3 & 67.7 \\
\hline \multicolumn{7}{|l|}{ Central Europe: } \\
\hline Austria & 79.4 & 96.1 & 84.6 & 91.9 & 71.8 & 102.2 \\
\hline Belgium & 68.4 & 78.3 & 73.9 & 74.4 & 60.5 & 83.9 \\
\hline Netherlands & 73.5 & 95.6 & 85.4 & 91.2 & 55.5 & 102.1 \\
\hline Germany & 67.9 & 80.6 & 71.3 & 83.9 & 62.1 & 75.9 \\
\hline Switzerland & 91.3 & 97.2 & 101.3 & 97.8 & 79.4 & 96.2 \\
\hline France & 72.4 & 93.5 & 75.0 & 92.5 & 68.8 & 94.8 \\
\hline Luxembourg & 75.9 & 94.2 & 85.1 & 96.2 & 61.4 & 91.1 \\
\hline UK & 87.3 & 99.3 & 94.5 & 95.4 & 77.9 & 104.9 \\
\hline Mean: & 91.8 & 90.4 & 93.9 & 77.0 & 83.9 & 67.2 \\
\hline U.S.A. & 100.0 & 100.0 & 100.0 & 100.0 & 100.0 & 100.0 \\
\hline$R^{2}$ & & 0.475 & & 0.784 & & 0.115 \\
\hline Corr (data,model) & & 0.326 & & 0.697 & & 0.011 \\
\hline
\end{tabular}

Note: This table displays hours worked as \% of U.S. hours in the data and in the model with alternative calibration of government transfers, after introducing taxes and divorce and marriage rates from other countries. Column (2) reports data and Column (3) reports the results when we simultaneously replace both the U.S. marriage and divorce probabilities and the tax system in the calibrated model with those obtained for each European country. Columns (4)-(7) repeat the exercise by gender. Overall the model explains $48 \%$ of the variation in labor supply between the U.S. and the European countries, as measured by $R^{2}$, which is similar that from the main calibration.

will disproportionately affect high earners. It is even possible that because of the tax progressivity, low earners face lower tax rates in Europe compared to the U.S. Another important feature of tax systems is joint vs. separate taxation. Guner et al. (2012) point out how separate taxation of married couples encourages female labor supply through lowering the tax rate on the secondary earner in a married couple (usually the female). ${ }^{21}$ Because of the gender wage gap, men are more likely to be among the high earners. Because countries with high average tax rates typically also have very progressive taxes and practice separate taxation of married couples, men bear most of the burden from the higher European tax rates.

To study the impact of tax structure vs. tax level, we conduct the following experiment. We start with our benchmark model, which we calibrated using the U.S. labor income taxes. Then we first change the labor income taxes so that the average labor income tax rate would be equal to that in Norway, but tax progressivity would remain the same as in the U.S. ${ }^{22}$ The degree to which couples are taxed jointly is also kept like in the U.S. in this experiment. Next, we change to a Norwegian tax system. We choose Norway because it is both among the countries in our sample for which the impact of the tax change on labor supply was much larger for men than for women. Norway has a highly progressive tax system and practices separate taxation of married couples.

Fig. 5 shows what happens to hours worked for men and women at different wage-quintiles as we change the tax system. The results confirm our intuition. As we change the U.S. taxes to the Norwegian tax level, keeping tax progressivity unchanged, the work hours schedule shifts downward - individuals at all wage-quintiles reduce their labor supply. As we change to a Norwegian tax system, the work hours schedule also changes its shape - because of the higher tax progressivity and separate taxation of married couples, the lowest earners actually increase their work hours, while higher earners reduce their work hours further.

\subsection{Intensive vs. extensive margin}

In Section 2 we documented that the intensive and extensive margins are about equally important in accounting for differences in labor supply between the U.S. and Europe but that the importance of the two margins varies greatly with region.

\footnotetext{
${ }^{21}$ Figure H.7 in the Appendix shows negative correlation between $s_{1}$ (our measure of joint taxation of married couples) and hours worked by married women.

${ }^{22}$ See Appendix F for the details.
} 
a

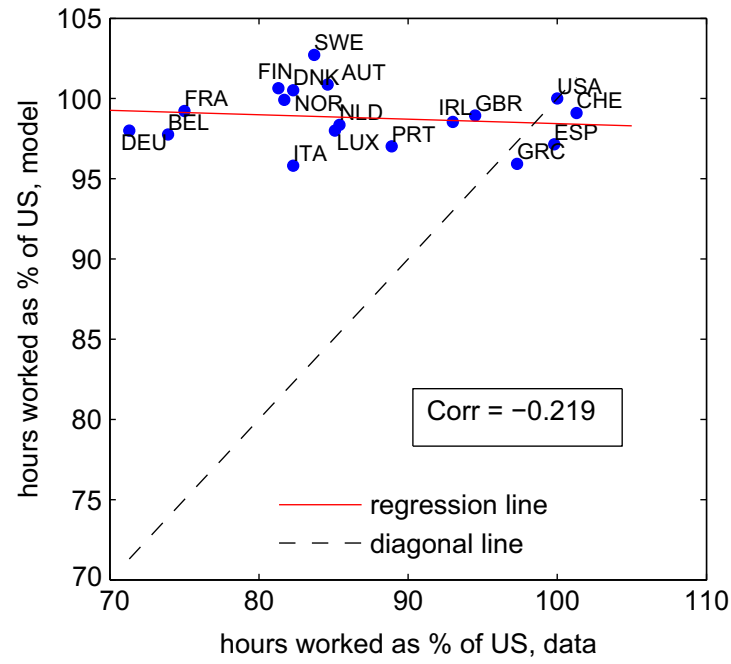

C

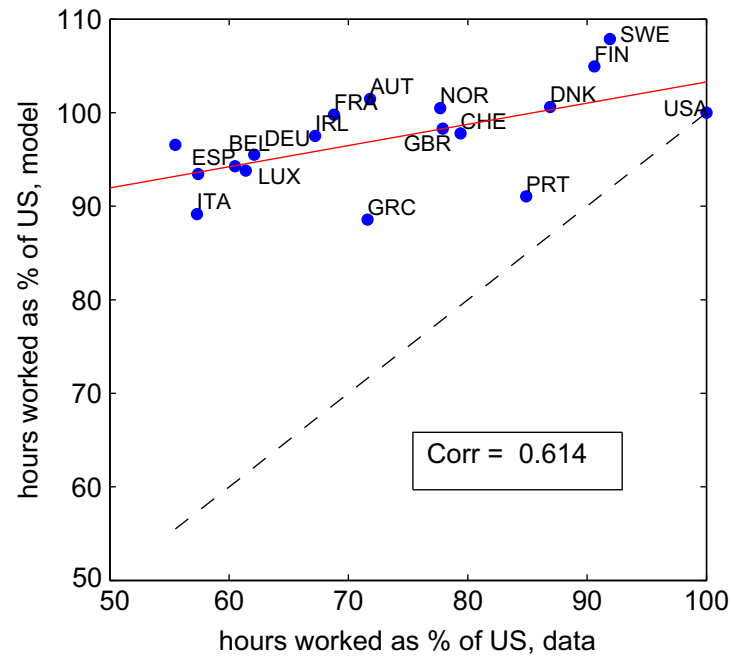

b

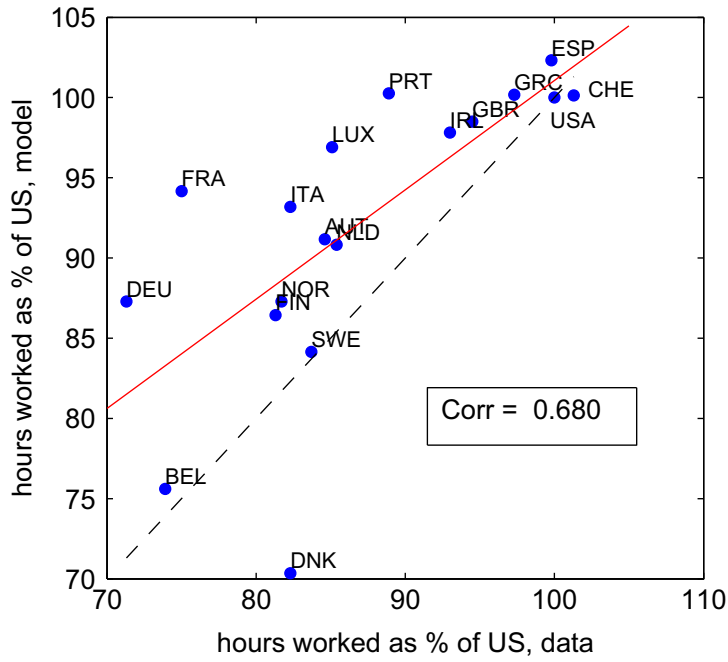

d

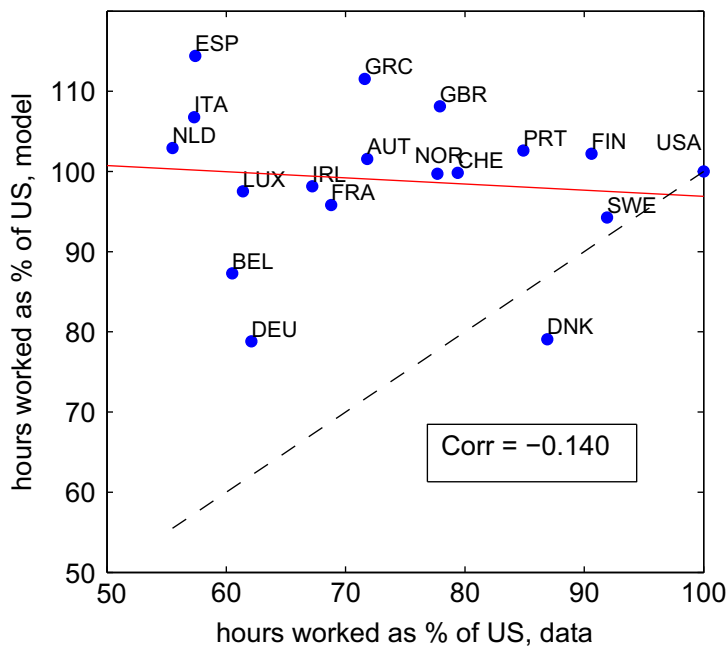

Fig. 4. Effects of marriage stability and taxes by gender. Note: This figure compares by gender, hours worked as percentage of U.S. hours in the data and in the model, after introducing taxes and divorce and marriage rates from other countries. The horizontal axis represents hours worked in each country relative to the U.S. (in percent) in the data. The vertical axis represents hours worked relative to the U.S. (in percent) in the model.

Table H.12 in the Appendix displays our model's performance in accounting for the intensive and extensive margin of labor supply across countries. We find that divorce and marriage probabilities explain $33 \%$ of the variation in employment rates between the U.S. and our European countries and do not help to explain the variation in the intensive margin. However, for taxes it is the other way around. Taxes explain $47 \%$ of the variation in intensive margin hours between the U.S. and the European countries but do not help in explaining the variation in the employment rates. This is similar to what we find in the data. ${ }^{23}$

\subsection{Discussion}

The correlation between female labor supply in the data and in our model when we introduce European divorce and marriage rates is quite strong, 0.61 . However as measured by $R^{2}$ we only explain $22 \%$ of the variation in female labor supply between the U.S. and our European countries. The effect of marriage and divorce rates pull in the right direction but the size of the effects is not that large.

A concern may be whether divorces are costly enough in the model. More costly divorces are likely to increase the impact of marriage and divorce probabilities on labor supply. For instance, we do not have children in the model. Children usually follow

\footnotetext{
${ }^{23}$ In unreported regressions, we find that when extensive and intensive margin labor supply is regressed on divorce rates and tax measures, taxes only help explain the variation in intensive margin labor supply and divorce rates only help explain the variation in extensive margin labor supply.
} 

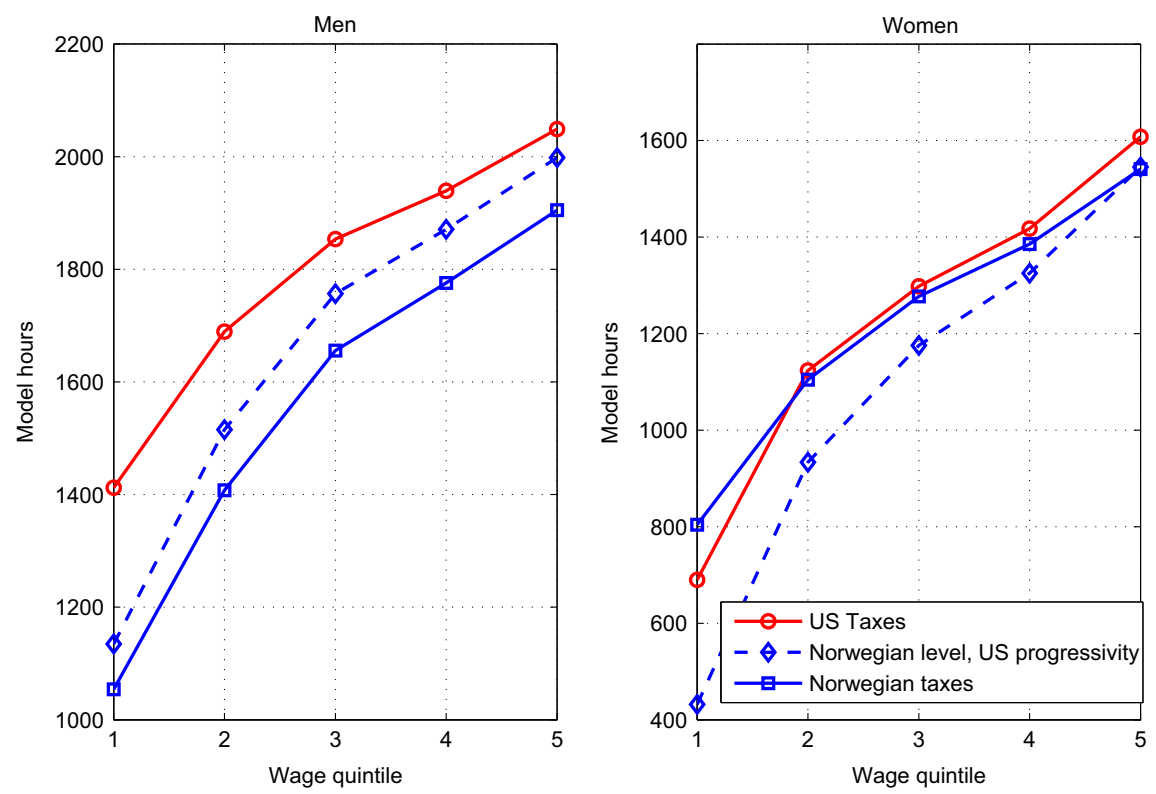

Fig. 5. Changing tax level vs. changing tax progressivity. Note: This figure reports how average hours worked over the life-cycle vary for men and women at different wage-quintiles (measure by life-time income) as the tax system changes.

their mother in the case of divorce, making divorce more costly for women (See Fernández and Wong, 2013 for a model that incorporates this effect). Cubeddu and Rios-Rull (2003) assume that 20\% of a couple's assets are lost when there is a divorce. This may be a reasonable assumption. Divorces carry large administrative costs, potential losses related to liquidation of home equity, reduced labor market mobility if there are children in the marriage, etc. We leave alternative specifications of the cost of divorce for future research but believe that the real cost of divorce is larger than in the current model.

\section{Conclusion}

In this paper we show that prime aged women are the largest contributor to differences in aggregate labor supply between the U.S. and Europe. We document a negative cross-country correlation between tax levels and labor supply and a positive correlation between divorce rates and labor supply across countries. However, the former correlation is driven by a strong correlation between male labor supply and taxes, whereas the latter correlation is driven by a strong correlation between female labor supply and divorce rates.

To quantify the impact of differences in tax schemes and divorce/marriage rates on labor supply, we develop a life-cycle, overlapping-generations model with heterogeneous agents, marriage, and divorce. We calibrate our model to U.S. data and study how labor supply in the U.S. changes as we introduce European tax systems, and as we replace the U.S. divorce and marriage rates with their European equivalents. Combining these two mechanisms can account for $45 \%$ of the variation in hours worked between the U.S. and the European countries. Taxes are a good predictor of male labor supply but do not help explaining the variation in female labor supply. Divorce and marriage rates can explain some of the variation in female labor supply across countries but is a worse predictor of male labor supply.

\section{Acknowledgments}

We thank Ricardo Reis (the Editor), one Anonymous Referee, Sören Blomquist, Harold Cole, Nils Gottfries, Urban Jermann, Dirk Krueger, Per Krusell, Iourii Manovskii, and Petra Todd for helpful discussions and comments. We also thank seminar participants at the University of Pennsylvania, Uppsala University, the University of Oslo, the Federal Reserve Board, the Federal Reserve Bank of Philadelphia, the Federal Reserve Bank of Dallas, the Federal Reserve Bank of New York, Bank of Norway, Bank of Hungary, Southern Methodist University, New Economic School, Göthe University Frankfurt, the 2013 AEA Annual Meeting (San Diego) the 5th Nordic Summer Symposium in Macroeconomics (Smögen), the 1st Joint French Workshop in Macroeconomics (Paris), the 2012 RES Annual Conference (Cambridge), the 2012 EEA Annual Meeting (Malaga), the 2011 National Conference of Swedish Economists (Uppsala), and our discussants Tobias Laun and Matthew Lindquist. Hans A. Holter is grateful for financial support from Handelsbanken Research Foundations, Browaldhstipend, and the Research Council of Norway, grant number 191884/V10 and grant number 219616; the Oslo Fiscal Studies Program. 


\section{Appendix A. Supplementary data}

Supplementary data associated with this article can be found in the online version at http://dx.doi.org/10.1016/j.jmoneco. 2015.01.001.

\section{References}

Adema, W., Fron, P., Ladaique, M., 2011. Is the European welfare state really more expensive? Indicators on social spending, 1980-2012; and a manual to the OECD social expenditure database (SOCX). Working Paper 124, OECD.

Alesina, A., Glaeser, E., Sacerdote, B., 2005. Work and leisure in the U.S. and Europe: why so different? NBER Macroecon. Annu. 1-64.

Attanasio, O., Low, H., Sanchez-Marcos, V., 2008. Explaining changes in female labor supply in a life-cycle model. Am. Econ. Rev. 98 (September (4)), $1517-1552$.

Benabou, R., 2002. Tax and education policy in a heterogeneous-agent economy: what levels of redistribution maximize growth and efficiency Econometrica 70, 481-517.

Bick, A., Fuchs-Schundeln, N., 2014. Taxation and labor supply of married couples across countries: a macroeconomic analysis. Working Paper, Goethe University Frankfurt

Blundell, R., Bozio, A., Laroque, G., 2011. Extensive and intensive margins of labour supply: working hours in the US, UK and France. IFS Working Paper Caucutt, E.M., Imrohoroglu, S., Kumar, K.B., 2003. Growth and welfare analysis of tax progressivity in a heterogeneous-agent model. Rev. Econ. Dyn. 6 (3), 546-577. Chang, Y., Kim, S.-B., 2006. From individual to aggregate labor supply: a quantitative analysis based on a heterogeneous-agent macroeconomy. Int. Econ. Rev. 47 (1), 1-27.

Crouch, J., Beaulieu, R., 2006. No-fault divorce laws and divorce rates in the United States and Europe: variations and correlations. In: Loveless, A.S., Holman, T.B. (Eds.), The Family in the New Millennium: Protecting the Natural and Fundamental Group Unit of Society, Praeger Publishing, Westport, CT. Cubeddu, L., Rios-Rull, J.V., 2003. Families as shocks. J. Eur. Econ. Assoc. 1, 671-682.

Fernández, R., Fogli, A., Olivetti, C., 2004. Mothers and sons: preference formation and female labor force dynamics. Q J. Econ. 119 (4), 1249-1299.

Fernández, R., Wong, J.C., 2013. Divorce risk, wages, and working wives: a quantitative life-cycle analysis of female labor force participation. Working Paper, New York University.

Furtado, D., Marcen, M., Sevilla-Sanz, A., 2010. Does culture affect divorce decisions? Evidence from European immigrants in the US. Working Paper 495 University of Oxford.

Gemici, A., Laufer, S., 2010. Marriage and cohabitation. Working Paper, New York University.

Goldin, C., Katz, L., 2002. The power of the pill: oral contraceptives and women's career and marriage decisions. J. Polit. Econ. 110 (4), 730-770.

Gonzalez, L., Viitanen, T.K., 2009. The effect of divorce laws on divorce rates in Europe. Eur. Econ. Rev. 53, $127-138$.

Greenwood, J., Seshadri, A., Yorukoglu, M., 2005. Engines of liberation. Rev. Econ. Stud. 72 (1), 109-133.

Guner, N., Kaygusuz, R., Ventura, G., 2012. Taxation and household labour supply. Rev. Econ. Stud. 79 (3), 1113-1149.

Guvenen, F., Kuruscu, B., Ozkan, S., 2014. Taxation of human capital and wage inequality: a cross-country analysis. Rev. Econ. Stud. 81 (2), 818-850.

Guvenen, F., Rendall, M., April 2013. Women's emancipation through education: a macroeconomic analysis. Working Paper 18979, National Bureau of Economic Research.

Heathcote, J., Storesletten, S., Violante, G., 2014. Optimal tax progressivity: an analytical framework. Working Paper, FRB Minneapolis, NYU and Oslo University. Heckman, J., 1976. The common structure of statistical models of truncation, sample selection and limited dependent variables and a simple estimator for such models. Ann. Econ. Social Meas. 5, 475-492.

Heckman, J., 1979. Sample selection bias as a specification error. Econometrica 47, 153-162.

Johnson, W., Skinner, J., 1986. Labor supply and marital separation. Am. Econ. Rev. 76, 455-469.

Jones, L.E., Manuelli, R.E., McGrattan, E.R., 2003. Why are married women working so much? Staff Report 317, Federal Reserve Bank of Minneapolis.

Kaygusuz, R., 2010. Taxes and female labor supply. Rev. Econ. Dyn. 13 (4), 725-741.

Keane, M.P., 2011. Labor supply and taxes: a survey. J. Econ. Lit. 49, 961-1045.

Kennes, J., Knowles, J., 2012. Can improved contraception account for the decline of marriage? Working Paper, University of Aarhus and University of Southampton. Kimmel, J., Kniesner, T.J., 1998. New evidence on labor supply: employment vs. hours elasticities by sex and marital status. J. Monet. Econ. 42 (2), 289-301. Kotlikoff, L.J., Spivak, A., 1981. The family as an incomplete annuities market. J. Polit. Econ. 89, 372-391.

McDermott, R., Fowler, J.H., Christakis, N.A., 2009. Breaking up is hard to do, unless everyone else is doing it too: social network effects on divorce in a longitudinal sample followed for 32 years. Working Paper, Brown University.

McKay, A., Reis, R., 2013. The role of automatic stabilizers in the U.S. business cycle. Working Paper 19000, NBER.

OECD, 2011. Organisation for economic co-operation and development: education at a glance. OECD Indicators.

Oh, H., Reis, R., 2012. Targeted transfers and the fiscal response to the great recession. J. Monet. Econ. 59 (S), S50-S64.

Olivetti, C., 2006. Changes in women's hours of market work: the role of returns to experience. Rev. Econ. Dyn. 9 (October (4)), $557-587$.

Perelli-Harris, B., Gassen, N.S., 2012. How similar are cohabitation and marriage? Legal approaches to cohabitation across Western Europe. Popul. Dev. Rev. 38 (3), 435-467.

Piketty, T., Saez, E., 2012. Optimal labor income taxation. Working Paper 18521, NBER.

Prescott, E.C., 2004. Why do Americans work so much more than Europeans. Fed. Reserve Bank Minneap. Q. Rev. 28 (1), $2-13$.

Rendall, M., 2011. The service sector and female market work: Europe vs U.S. Working Paper, University of Zurich.

Rogerson, R., 2006. Understanding differences in hours worked. Rev. Econ. Dyn. 6, 365-409.

Stevenson, B., 2008. Divorce law and women's labor supply. J. Emp. Legal Stud. 5 (4), 853-873.

Tauchen, G., 1986. Finite state Markov-chain approximations to univariate and vector autoregressions. Econ. Lett. $20,177-181$.

Trabandt, M., Uhlig, H., 2011. The Laffer curve revisited. J. Monet. Econ. 58 (4), 305-327.

Wallenius, J., 2012. Social security and cross-country differences in hours: a general equilibrium analysis. Working Paper, Stockholm School of Economics. 